\title{
KAJIAN BIBLIKA KECEMBURUAN ALLAH TERHADAP PENYEMBAHAN BERHALA BERDASARKAN KELUARAN 20:4-6
}

\author{
Queency Christie Wauran ${ }^{1)^{*}}$ \\ 1)Mahasiswa Program Pascasarjana Prodi Teologi Sekolah Tinggi Theologia Jaffray \\ *Penulis korespondensi: queencychristie23.qc@gmail.com
}

\begin{abstract}
Abstrak
Dalam Perjanjian Lama kecemburuan Allah selalu berada dalam konteks penyembahan berhala. Hukum Taurat yang kedua dengan jelas melarang penyembahan kepada patung oleh karena alasan ini yaitu Allah yang cemburu. Tujuan penulisan artikel ini adalah untuk mengetahui arti kecemburuan Allah terhadap penyembahan berhala berdasarkan kitab Keluaran 20:4-6 dan implikasinya bagi kehidupan orang percaya. Adapun kesimpulan artikel ini adalah pertama, kecemburuan Allah terhadap penyembahan berhala menyatakan bahwa Allah tidak dapat direpresentasikan dalam bentuk apapun karena kecemburuan Allah ini menyatakan bahwa Ia adalah Allah yang kudus. Dengan demikian, hanya Allah satu-satunya yang harus disembah oleh orang percaya. Kedua, kecemburuan Allah terhadap penyembahan berhala menyatakan bahwa tidak boleh ada objek penyembahan yang lain selain kepada Allah karena penyembahan kepada berhala menandakan perzinaan rohani yang mengakibatkan kecemburuan Allah. Oleh karena itu, orang percaya harus menolak segala bentuk penyembahan berhala. Ketiga, penyembahan kepada berhala mendatangkan kecemburuan Allah karena kecemburuan Allah ini menyatakan kesetiaan-Nya atas perjanjian dengan umat-Nya. Dengan demikian, kecemburuan Allah seharusnya menjadi dasar dari penyembahan kepada Allah. Keempat, kecemburuan Allah atas penyembahan berhala mendatangkan hukuman karena kecemburuan Allah menyatakan keadilan-Nya dalam hal pemberian hukuman sebagai konsekuensi bagi penyembah berhala. Kelima, kecemburuan Allah atas penyembahan berhala menyatakan bahwa Allah mengasihi umat-Nya dan sekaligus menyatakan keadilan Allah dalam hal pemberian berkat bagi yang mengasihi-Nya. Kasih Allah mendasari hubunganNya dengan umat-Nya, dengan demikian kasih juga menjadi dasar hubungan orang percaya dengan Allah.
\end{abstract}

Kata kunci: Kecemburuan Allah, penyembahan, berhala, hukuman, kasih, hubungan, perzinaan rohani, Keluaran 20:4-6.

In the Old Testament, the jealousy of God is always in the context of worshipping idols. The second commandment clearly prohibits the worshipping of statues for this reason, that God is jealous. This article is based on Exodus 20:4-6, and its purpose is to understand the meaning of God's jealousy with respect to the worship of idols and its implications in the lives of believers. Now, the summary of this article is firstly: the jealousy of God in 
respect to idolatry says that God cannot be represented in any shape or form whatsoever because the jealousy of God says that He is a God who is Holy. As such, only God Himself should be worshipped by believers. Secondly, the jealousy of God in respect to idolatry says that there is to be no other object of worship other than God because the worship of idols signifies spiritual adultery that results in the jealousy of God. Because of this, believers must reject all forms of idolatry. Thirdly, idolatry brings about the jealousy of God because of God's faithful covenant with His people. Thus, the jealousy of God should become the foundation of worship to God. Fourthly, the jealousy of God in relation to idolatry brings about judgment because the jealousy of God says that He is just when giving judgment as a consequence for worshipping idols. Fifthly, the jealousy of God in relation to idolatry says that God loves His people and at the same time says that God is just in giving blessings to those who love Him. The love of God underlies the relationship God has with His people. As such, love also becomes the foundation of the relationship believers have with God.

Key words: Jealousy of God, worship, idolatry, judgment, love, relationship, spiritual adultery, Exodus 20:4-6

\section{Pendahuluan}

Ketika Allah membawa bangsa Israel keluar dari Mesir ke Sinai, untuk memberi mereka hukum Taurat dan perjanjian-Nya, kecemburuan-Nya merupakan salah satu fakta yang Ia ajarkan tentang diri-Nya, "Aku, Tuhan, Allahmu adalah Allah yang cemburu" (Kel. 20:5). Bahkan dalam pertemuan kembali di atas gunung Sinai, Allah dengan jelas mengatakan kepada Musa, "TUHAN, yang nama-Nya Cemburuan, adalah Allah yang cemburu" (Kel. 34:14). Menarik bahwa kecemburuan Allah ini pertama kali muncul dan dicatat dalam kitab Keluaran. Di sinilah untuk pertama kalinya Allah menyatakan bahwa Ia adalah Allah yang cemburu.

Dalam Perjanjian Lama, kecemburuan Allah itu selalu dikaitkan dengan penyembahan berhala. Dalam tulisannya, Nizzim Amzallag menjelaskan bahwa kecemburuan Allah merupakan atribut utama Allah yang penting dan menjadi elemen dasar dalam Perjanjian Lama mengenai Allah. ${ }^{1}$ Demikian juga J. I. Packer menyatakan bahwa referensi Musa tentang kecemburuan Allah berkaitan dengan salah satu bentuk penyembahan berhala atau yang lain. ${ }^{2}$ Secara spesifik hal ini terlihat dalam hukum kedua:

${ }^{1}$ Nizzim Amzallag, "Furnace Remelting as the Expression of YHWH's Holiness: Evidence from the Meaning of qanna $\bar{a}$ (קנא ) in the Divine Context" Journal of Biblical Literature. Vol. 134 No. 2 (2015): 233.

2 J. I. Packer, Knowing God, Tuntunan Praktis Untuk Mengenal Allah (Yogyakarta: Penerbit ANDI, 2008), 216. 
Jangan membuat bagimu patung yang menyerupai apapun yang ada di langit di atas, atau yang ada di bumi di bawah, atau yang ada di dalam air di bawah bumi. Jangan sujud menyembah kepadanya atau beribadah kepadanya, sebab Aku, Tuhan, Allahmu, adalah Allah yang cemburu, yang membalaskan kesalahan bapa kepada anak-anaknya, kepada keturunan yang ketiga dan keempat dari orang-orang yang membenci Aku, tetapi Aku menunjukkan kasih setia kepada beribu-ribu orang, yaitu mereka yang mengasihi Aku dan yang berpegang pada perintah-perintah-Ku. ${ }^{3}$

Kecemburuan Allah selalu muncul berkaitan dengan penyembahan kepada patung. Frank E. Gaebelein menuliskan bahwa kata cemburu yang digunakan kepada Allah selalu dijelaskan paralel antara penyembahan berhala dan perzinaan. ${ }^{4}$ Allah secara tegas tidak mau adanya penyembahan kepada berhala. Menarik bahwa George Arthur Buttrick kemudian menjelaskan tentang alasan Allah menentang penyembahan berhala yaitu bahwa alasan yang paling kuat dan pribadi mengapa orang Israel diperintahkan "jangan ada allah lain" ialah bahwa penyembahan berhala membangkitkan kecemburuan Allah. ${ }^{5}$ Sejak Allah dan bangsa Israel mengikat perjanjian di gunung Sinai maka Israel menjadi milik Allah sehingga Israel harus menyembah Allah sendiri dan Israel dilarang menyembah berhala.

Dalam situasi pada masa kini, tidak dapat dipungkiri bahwa penyembahan berhala itu masih ada. David Orton menuliskan bahwa kegagalan umat Allah sepanjang sejarah adalah penyembahan berhala yaitu penyembahan terhadap ilah-ilah asing. ${ }^{6}$ Walaupun dalam kenyataannya memang berhala yang dimaksud tidak lagi sama seperti pada zaman bangsa Israel. Jerry Bridges menjelaskan dalam bukunya Respectable Sins Membereskan Dosa-Dosa Yang Kita Toleransi:

Kita bukan sedang menyembah berhala-berhala dari kayu, logam, dan batu pada masa kini. Masalah kita adalah apa yang oleh sebagian orang disebut "berhala-berhala hati." Dalam pengertian ini, sebuah berhala dapat berarti apa saja yang sangat kita junjung tinggi yang cenderung menyerap energi emosional dan mental kita, atau waktu sumber daya kita. Atau berhala dapat berupa apa saja yang kita dahulukan di atas relasi kita dengan Allah. ${ }^{\top}$

\footnotetext{
${ }^{3}$ Keluaran 20:4-6, TB.

${ }^{4}$ Frank E. Gaebelein, The Expositor's Bible Commentary With The New Internasional Version Volume 2 (Grand Rapids, Michigan: Zoncervan Publishing House, 1990), 486.

5 George Arthur Buttrick, The Interpreter's Dictionary Of The Bible An Illustrate Encyclopedia In Four Volumes (New York, Nashville: Abingdon Press, 1962), s.v. "Idolatry"

${ }^{6}$ David Orton, Ular-ular Dalam Gereja (Yogyakarta: Penerbit ANDI, 2005), 70.

7 Jerry Bridges, Respectable Sins Membereskan Dosa-dosa yang Kita Toleransi (Bandung: Pionir Jaya, 2008), 195-196.
} 
Penyembahan berhala pada masa kini memiliki model berhala yang berbeda yang disebut berhala modern yang menghalangi relasi yang seharusnya antara Allah dengan manusia. Hal inilah yang mengakibatkan kecemburuan Allah bangkit terhadap umat-Nya.

Menarik karena konsep mengenai kecemburuan Allah ini seringkali disalahmengerti oleh orang percaya. Memang dari kata "cemburu" sendiri bisa menimbulkan banyak penafsiran, yang bisa membuat orang salah memahami tentang kecemburuan Allah. Berdasarkan asal kata Ibrani, kata yang digunakan untuk cemburu adalah qin'a. Kata qin'a berarti suatu perasaan tidak senang terhadap seseorang yang memiliki sesuatu, yang tidak dimiliki sendiri. ${ }^{8}$ Kata inilah yang digunakan untuk menggambarkan sikap Rahel yang cemburu terhadap kakaknya (Kej. 30:1). Dalam bagian lain seperti dalam Amsal 27:4, kata cemburu ini menggambarkan keburukan, dan dalam Amsal 14:30 kata cemburu yang digunakan diterjemahkan dengan iri hati. Berdasarkan arti kata tersebut, orang percaya kadangkala salah berpikir tentang Allah yang cemburu bahwa kecemburuan Allah itu sama halnya dengan manusia. Apalagi kecemburuan Allah sering dikaitkan dengan hukuman oleh karena murka-Nya yang bangkit. Sehingga pemahaman yang benar mengenai arti kecemburuan Allah sangat dibutuhkan serta alasan mengapa kecemburuan Allah ini selalu berkaitan dengan penyembahan berhala.

\section{Makna Leksikal Allah Cemburu}

Kata "cemburu" dalam Perjanjian Lama diterjemahkan dari kata dasar dalam bahasa Ibrani qannā. Pengertian dasar qanna adalah "menjadi merah pada wajah". ${ }^{9}$ Kata qannā adalah kata yang berarti cemburu (jealous). ${ }^{10}$ Sebagai kata kerja, qannā digunakan untuk menyatakan atau menunjukkan suatu perasaan yang kuat di mana subjek sangat menginginkan sesuatu aspek atau kepemilikan dari objek. ${ }^{11}$ Berasal dari kata qin'a aslinya ialah menyala, kemudian berarti warna merah yang kelihatan pada wajah seseorang yang diliputi perasaan membara, lalu perasaan tidak senang terhadap seseorang yang memiliki sesuatu, yang tidak dimiliki sendiri. ${ }^{12}$ Sebagai kata benda, kecemburuan menggambarkan suatu kekuatan semangat yang bernyala-nyala,

${ }^{8}$ Ensiklopedi Alkitab Masa Kini Jilid I A-L, s.v. "cemburu”

${ }^{9}$ The Interpreter's Dictionary of the Bible (New York: Abingdon Press), s.v. qanna.

${ }^{10}$ James Strong, Strong Exhaustive Concordance of the Bible, Reference Library Edition (Iowa Falls, Iowa: World Bible Publishers, n.d), s.v qanna.

${ }^{11}$ Wordstudy, e-Sword-the Sword of the Lord with an electronic edge, s. v. qanna.

12 J. D. Douglas, Ensiklopedi Alkitab Masa Kini Jilid l (Jakarta: Yayasan Komunikasi Bina Kasih, 1992), 213. 
perasaan yang sangat kuat, dan emosi atau perasaan hati yang melebihi kemarahan dan murka seseorang. ${ }^{13}$ Hal yang menarik adalah kata "jealous" (qanna) ini digunakan hanya untuk Tuhan, terdapat hanya lima kali dalam Perjanjian Lama dan pertama kali muncul di Keluaran 20:5 dan dijelaskan paralel antara penyembahan berhala dan perzinaan. ${ }^{14}$ Kata ini tidak dipakai dalam arti atau implikasi yang jelek. Dalam suatu terjemahan Yahudi, kata impassioner yang dipakai, yaitu Tuhan berperasaan dalam atau bersemangat. ${ }^{15} \mathrm{Hal}$ ini juga berarti perasaan yang lain, yaitu keinginan untuk menjaga dan mempertahankan supaya jangan hilang, apa yang dimilikinya sendiri. Dalam pengertian ini, Allah disebut juga cemburu (Kel. 34:14), sebab Dia mempertahankan hak-Nya sebagai Satu-satunya yang boleh disembah, dan tidak akan memberikan kemuliaan-Nya kepada orang lain (Yes. 42: 8). Sebagai mempelai Israel yang setia Ia menuntut supaya mereka setia terhadap Dia. ${ }^{16}$

Kamus Webster memberikan definisi untuk kata "cemburu" yaitu khawatir kehilangan pengabdian yang eksklusif, tidak toleransi terhadap persaingan atau ketidaksetiaan, memusuhi seseorang yang dipercaya untuk menikmati sebuah keuntungan, dan waspada untuk menjaga apa yang menjadi miliknya. ${ }^{17}$ Keempat aspek kecemburuan ini jelas dalam Keluaran 20:5. Allah memiliki perhatian yang mendalam, semangat untuk tidak kehilangan pengabdian eksklusif yang seharusnya dimiliki oleh orang percaya kepada-Nya. Allah juga tidak menoleransi persaingan atau ketidaksetiaan. Ia juga bermusuhan terhadap berhala-berhala yang menikmati keuntungan dari pengabdian yang seharusnya menjadi milik Allah. Bahkan Ia memusuhi orang-orang yang bertahan dalam ketidaksetiaan mereka kepada-Nya. Dan Allah juga waspada terhadap apa yang menjadi milik-Nya yaitu pengabdian dengan setia ditunjukkan oleh orang percaya di hadapan Allah.

Berdasarkan studi akar kata Ibrani Kuno untuk kata qannā terdapat penjelasan yang kaya dan mendalam mengenai Allah cemburu. Jeff A. Benner menjelaskan dalam Ancient Hebrew Research Center bahwa penulisan Ibrani kuno ditulis dalam bentuk gambar atau simbol. Jadi, dengan memahami gambar itu akan memberikan pemahaman bagaimana mereka menggunakan dan maksud dari kata tersebut. Setiap simbol itu memiliki

${ }^{13}$ Wordstudy, e-Sword-the Sword of the Lord with an electronic edge, s. v. qina.

${ }^{14}$ Frank E. Gaebelein, The Expositor's Bible Commentary With The New Internasional Version Volume 2 (Grand Rapids, Michigan: Zoncervan Publishing House, 1990), 486.

${ }^{15}$ Robert Paterson, Kitab Keluaran (Jakarta: Bpk Gunung Mulia, 2006), 263.

${ }^{16}$ J. D. Douglas, Ensiklopedi Alkitab Masa Kini Jilid 1 (Jakarta: Yayasan Komunikasi Bina Kasih, 1992), 213.

${ }_{17}$ W. T. Harris \& F. Sturges Allen, Webster's New Internasional Dictionary of the English Languange (Springfield, Mass., USA: G \& C Merriam Company, 1915), s.v. jealous. 
arti tersendiri. Kata qannā dibentuk dari "Q" yang merupakan simbol matahari terbit dan terbenam. Bagi orang Ibrani, matahari mengumpulkan terang pada sunset dan gelap pada subuh. Matahari terbit dan terbenam dimengerti sebagai perputaran bumi. Arti simbol ini adalah matahari berputar mengakibatkan berkumpulnya terang dan gelap. "N" adalah simbol dari benih. Benih dimengerti sebagai permulaan kehidupan bagi induk tanaman. Dari situlah secara terus menerus menghasilkan banyak tanaman yang lain. Arti simbol itu adalah bersambungnya kehidupan dari sebuah benih. Digabungkan menjadi "QeN" yang merupakan simbol dari mengumpulkan benih-benih. Sesuai dengan budayanya, sebelum seekor burung meletakkan telur-telurnya, ia terlebih dahulu pergi mencari dan mengumpulkan bahan-bahan untuk membangun sarangnya. Arti simbol ini adalah pengumpulan bahanbahan untuk membuat sarang bagi benih yaitu telurnya. Dan digabungkan lagi menjadi "Qa-Neh" yang artinya membuat sarang. Simbol ini disebut sebagai pembuat sarang, seperti burung. Hal yang menarik dalam Kejadian, Allah dikatakan bereshyit: Allah adalah pencipta (qaneh) langit dan bumi. Di saat orang melihat bahwa Allah menciptakan dari tidak ada menjadi ada, orang-orang Ibrani melihat Allah seperti burung yang pergi mencari dan mengumpulkan bahanbahan untuk membuat sarang (qen), yaitu langit dan bumi. Orang-orang Ibrani memandang manusia sebagai anak (telur) yang untuknya Allah membangun sarang. ${ }^{18}$

Selanjutnya muncullah kata qannāa. Arti simbol ini adalah untuk melindungi. Akar kata ini adalah to guard (sering diartikan cemburu). Seekor burung menjaga telur-telurnya yang masih baru dengan cemburu dan akan mempertahankannya dari musuh dan mencegah burung yang lain untuk masuk ke sarang. Jadi, dengan penggabungan simbol tersebut dapat dimengerti dengan lebih baik bahwa inilah gambaran bahasa Ibrani dalam menjelaskan Allah yang cemburu di Keluaran 20:5. Sama seperti seekor burung yang melindungi telur-telurnya dari pemangsa (perbuatan, bukan hanya emosi) demikian juga Tuhan menjaga anakanak-Nya di sarang dan melindungi mereka dari pemangsa-pemangsa yaitu ilah-ilah yang lain. ${ }^{19}$ Jadi, maksud Allah cemburu adalah Ia ingin melindungi apa yang menjadi milik-Nya dan Ia tidak mau disaingi oleh siapapun atau ciptaan-Nya berpaling kepada siapapun termasuk kepada ilah-ilah yang lain. Dia ingin agar anak-anak-Nya hidup dalam pemeliharaan-Nya.

18 Jeff A. Benner. "Ancient Hebrew Research Center," diakses 4 Desember 2012, http://www.ancient-hebrew.org/5_creator.html

${ }^{19}$ Ibid. 


\section{Analisis Teks Keluaran 20:4-6}

\section{Ayat 4}

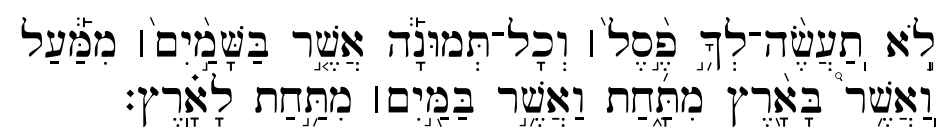

Frasa lo taaseh-leka diterjemahkan sebagai thou shall not make, yang dalam bahasa Indonesia berarti "Jangan membuat bagimu". Kata lo diterjemahkan sebagai shall not, sebagai kata tugas dalam bahasa Indonesia berarti tidak atau jangan. ${ }^{20}$ Kata taaseh adalah bentuk kata kerja qal imperfek orang kedua tunggal maskulin. Berasal dari kata asa yang berarti membuat. Kata ini diterangkan dengan dua kali akusatif, sehingga terjemahan harfiahnya menjadi "membuat, seperti kesamaannya dan dalam bentuk apapun, yang ada di langit, dan seterusnya." ${ }^{21}$

Kata pesel atau graven image/idol yang berarti patung yang dipahat atau diukir dari kayu atau batu. ${ }^{22}$ Kata pesel yang diartikan graven image, berasal dari akar kata yang berarti "to carve." Asal kata ini dengan jelas berarti sebuah objek yang dipahat. Tetapi itu juga menjadi istilah yang umum untuk patung, apakah diukir/pahat ataupun dituang (Yes. 30:22; 40:19; 44:10; Yer. 10:14). Saat digunakan untuk patung tuangan selalu menunjuk kepada berhala (20:4). Patung tuangan dilarang dalam ayat 23 dan 34:17. ${ }^{23}$ Kata ini juga menunjuk kepada sebuah gambar yang terbuat dari kayu atau batu, dan terdapat dalam Yosua 17:3 sebagai gambar representasi Yehovah, dan dalam bagian lain sebagai gambaran dari dewa-dewa penyembah berhala, contohnya Asyera (2 Raj. 21:7). ${ }^{24}$

Istilah pesel yang dimaksud bukan saja menunjuk kepada "patung pahatan" saja tetapi juga "patung tuangan" (Yes. 40:19; 44:10; Yer. 10:14) karena patung tuangan juga kebanyakan diselesaikan dengan menggunakan alat ukiran. ${ }^{25}$ Robert Patterson menambahkan pula bahwa meskipun kata ini diterjemahkan sebagai "patung pahatan" (Ul. 27:15), dan "patung tuangan" disebut juga di sana, tetapi pastilah semua macam patung ditunjukkan di sini, yaitu patung pahatan yang terbuat dari kayu, tanah liat, atau batu dan patung tuangan yang terbuat dari logam. ${ }^{26}$

${ }^{20}$ (WTM Morphology, Word Analysis, In Bible Works Version 7), s.v. "לּר"

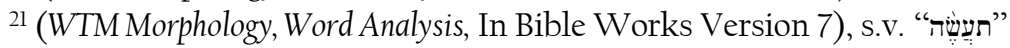

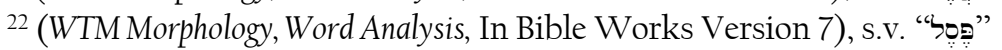

${ }^{23}$ George Arthur Buttrick, The Interpreter's Bible The Holy Scriptures Volume I General And Old Testament Articles Genesis-Exodus (Nashville: New York Abingdon Press, 1952), 981-982.

${ }^{24}$ Keil \&EDelitzsch, Commentary On The Old Testament, e-Sword.

${ }^{25}$ The Pulpit Commentary, e-Sword.

26 Robert M. Patterson, Tafsiran Alkitab Kitab Keluaran (Jakarta: BPK Gunung Mulia, 2006), 262. 
Maka kata pesel mencakup patung pahatan atau tuangan atau ukiran baik yang terbuat dari kayu, batu, tanah liat ataupun logam.

Namun perintah dalam ayat 4 tidak melarang semua ukiran dan lukisan. ${ }^{27}$ Ukiran dan lukisan untuk karya seni tidak dilarang namun yang dilarang adalah setiap usaha penggambaran Allah dengan tujuan untuk disembah.

Frasa wakol-temunah, diterjemahkan sebagai or any likeness, yang dalam Bahasa Indonesia diterjemahkan "yang menyerupai apapun." Kata wakol menggunakan (wa-) sebagai partikel penghubung yang berarti semua, segala, apapun..$^{28}$ Kata temunah adalah kata benda umum tunggal feminine absolut, yang berarti bentuk atau keserupaan. ${ }^{29}$ Ide utama dari kata ini merupakan sesuatu kemiripan atau kesamaan. Kata ini biasanya digunakan untuk menggambarkan larangan Allah, untuk menciptakan gambar apapun yang coba menyerupai (atau menjadi seperti) Dia. ${ }^{30}$ Sehingga membuat gambar apapun untuk mewakili atau menggambarkan kesamaan Allah jelas dilarang.

Kata temunah bukan hanya menunjuk kepada "yang menyerupai" tetapi kata ini juga menunjuk kepada penampilan, bentuk, atau representasi yang mana tidak kelihatan. Ayat 4 ini sangat jelas harus dipahami dalam pengertian ini. Kata "yang menyerupai" saja tidak menyampaikan arti yang sesungguhnya dari kata itu. Jadi, hukum kedua dengan pasti melarang semua representasi atau simbolisasi objek Ilahi untuk penyembahan. ${ }^{31}$ Jadi semua penggambaran, representasi maupun simbolisasi Allah tidak diijinkan apakah itu kelihatan maupun tidak kelihatan.

Frasa aser bassamayim mimmaal, diterjemahkan sebagai any thing that is in heaven above, yang dalam Bahasa Indonesia diterjemahkan "yang ada di langit di atas." Kata bassamayim berasal dari kata shamayim, dengan (ba-) sebagai partikel penghubung dan (ha-) merupakan awalan penentu. Kata shamayim adalah bentuk kata benda jamak maskulin berarti surga atau langit. ${ }^{32}$ Langit di mana manusia melihat dengan indera ditunjukkan oleh kata ini. Bintang-bintang yang menjadi bagian dari langit, dan dipersonifikasikan dalam beberapa kasus. Matahari dan bulan, termasuk bintang-bintang yang membuat sebagian besar bala tentara langit.

${ }^{27}$ F. Davidson, A. M. Stibbs, E. F. Kevan, The New Bible Commentary (Grand Rapids, Michigan: WM. B. Eerdmans Publishing Company, 1965), 120.

28 (WTM Morphology, Word Analysis, In Bible Works Version 7), s.v. "זְְָ"

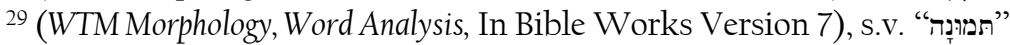

30 Wordstudy, e-Sword-the Sword of the Lord with an electronic edge, s. v. "תמוּנד"

31 William Wilson, Wilson's Old Testament Word Studies (Mclean: Mac Donald Publishing Company, n.d.), 254.

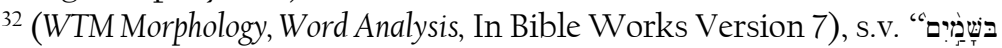


Sayangnya, hal ini disembah sebagai allah bahkan oleh orang Israel. Langit menjadi sumber untuk mengetahui masa depan dan kehidupan secara umum. Langit menjadi berhala kafir favorit yang disebut ratu sorga yang kepadanya orang sujud menyembah. ${ }^{33}$

"That which is in heaven" yang dimaksud adalah burung-burung, bukan malaikat-malaikat, atau menurut Ulangan 4:19, bintang-bintang. Pulpit menafsirkan bentuk apapun dari burung bersayap di udara (bnd. Ul. $4: 17){ }^{34}$

Frasa waaser baares mittaahat, diterjemahkan or that is in the earth beneath, yang diterjemahkan dalam Bahasa Indonesia "atau yang ada di bumi di bawah." 35 Kata baares merupakan kata benda tunggal feminine dengan kata depan (ba-). ${ }^{36}$

"Di bawah bumi" ditambahkan ke "air", adalah untuk mengekspresikan gambaran ide yang lebih rendah dari pada tanah (bnd. 4:18). Hal ini tidak hanya jelas dari konteks bahwa kiasan itu bukan untuk menggambarkan aslinya, tetapi untuk membentuk gambaran Allah sebagai objek dari agama atau penyembahan, inilah yang secara tegas dinyatakan pada ayat ini. ${ }^{37}$

Frasa waaser bammayim mittahat laares, yang diterjemahkan or that is in the water under the earth, yang dalam Bahasa Indonesia diterjemahkan "atau yang ada di dalam air di bawah bumi." Yang ada di dalam air di bawah bumi, ini menunjukkan kepada kepercayaan pada waktu itu yang mempercayai bahwa bumi itu datar (Yes. 40:22) mengapung di atas lubang yang penuh dengan air (Kej. 1:6; 7:11). Tiga bagian yang disebutkan di sini dan di tempat lain menunjukkan cakupan semua materi alam semesta (bnd. Kej. 1:6-7). Kebanyakan agama di Mesir terdiri atas penyembahan kepada binatang dan patung-patungnya. ${ }^{38}$

Dengan demikian ayat 4 ini menguraikan bagian hukum kedua yang mana bangsa Israel dengan jelas dan tegas dilarang untuk membuat patung atau gambar dalam bentuk apapun, baik yang merepresentasikan Allah Israel yang benar maupun sebagai simbolisasi allah-allah lain atau berhala lain, yang terbuat dari apa saja baik batu, kayu, tanah liat, besi, logam dan sebagainya, yang menyerupai apapun itu di bumi, yang di langit di atas, di bumi di bawah, atau di dalam air di bawah bumi, yang kelihatan maupun tidak kelihatan oleh manusia.

\footnotetext{
${ }^{33}$ Wordstudy, e-Sword-the Sword of the Lord with an electronic edge, s. v. "weve

${ }^{34}$ The Pulpit Commentary, e-sword.

35 (WTM Morphology, Word Analysis, In Bible Works Version 7), s.v. "יואיאוּר"

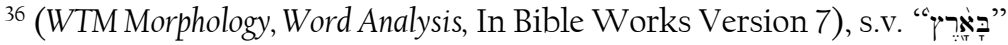

${ }^{37}$ Keil \& Delitzsch, Commentary On The Old Testament, e-Sword

${ }^{38}$ The Pulpit Commentary, e-Sword.
} 
Ayat 5

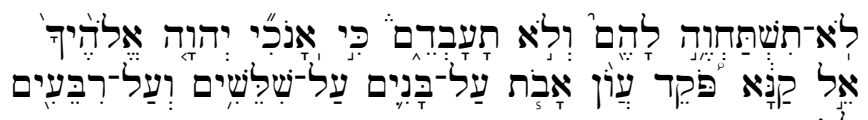

לשישנאי:

Frasa lo-tistahweh lahem diterjemahkan thou shalt not bow down thyself to them, yang dalam Bahasa Indonesia diterjemahkan "Jangan sujud menyembah kepadanya". Kata lo-tistahweh adalah bentuk kata kerja hishtaphel imperfek orang kedua tunggal maskulin dengan (lo-) sebagai partikel negatif. ${ }^{39}$ Kata ini juga menunjuk kepada penyembahan yang benar kepada Tuhan. ${ }^{40}$

Kata lahem diterjemahkan mereka. Akhiran kepada mereka, dan mereka ini mengacu pada hal-hal di langit, di bumi, di dalam air di bawah bumi (ay. 4), yang dijadikan patung sebagai lambang Yehovah, sebagai objek pokok yang disembah. ${ }^{41}$ Akhiran kata ini yang dalam bentuk jamak juga menunjuk kepada "allah lain" dalam ayat 3 yang juga dalam bentuk jamak. ${ }^{42}$ Jadi larangan ini termasuk pada larangan untuk menyembah patung sebagai lambang Allah termasuk objek lain yang menggambarkan allah lain, dengan jelas dilarang.

Frasa welo toobdem yang diterjemahkan nor serve them, yang dalam bahasa Indonesia diterjemahkan "beribadah kepadanya". Kata toobdem adalah bentuk kata kerja hofal imperfek orang kedua tunggal maskulin akhiran orang ketiga jamak maskulin..$^{43}$ Kombinasi kedua kata kerja ini (tistahweh dan toobdem) seperti biasa menunjuk kepada penyembahan berhala (Ul. 17:3; 30:17; Yer. 8:2). Keduanya harus dimengerti sebagai hendiadys: you will not prostate yourself to serve them. ${ }^{44}$ Kata hendiadys merupakan sebuah kiasan di mana dua ekspresi ini digunakan untuk menyampaikan ide tunggal, yaitu untuk menawarkan ibadah (ay. 5a). Ekspresi ini hanya digunakan sehubungan dengan penyembahan kepada dewa asing yang dilarang untuk orang Israel.45 Jadi bagian ini menyatakan dengan tegas larangan untuk menyembah dan beribadah kepada berhala yang dibuat tersebut. Ibadah sama sekali tidak ditujukan kepada berhala. Karena alasannya ada pada kalimat selanjutnya.

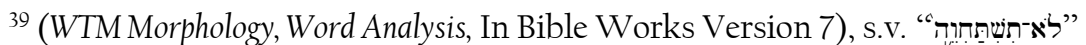

40 Text footnotes for NET Version, Word Analysis In Bible Works Version 7.

${ }^{41}$ Keil \& Delitzsch, Commentary On The Old Testament, e-Sword

42 Robert M.Patterson, Tafsiran Alkitab Kitab Keluaran (Jakarta: BPK Gunung Mulia, 2006), 263.

43 (WTM Morphology, Word Analysis, In Bible Works Version 7), s.v. "תעָּבְברָם"

${ }^{44}$ Text footnotes for NET Version, Word Analysis In Bible Works Version 7

45 Frank E. Gaebelein, The Expositor's Bible Commentary with The New International Version Volume 2 (Grand Rapids, Michigan: Zondervan Publishing House, 1990), 423.
} 
Frasa ki anoki YHWH (adonay) eloheka yang diterjemahkan for I the LORD thy God, yang dalam bahasa Indonesia diterjemahkan "sebab Aku, TUHAN Allahmu." Kata anoki adalah bentuk kata ganti orang pertama tunggal. Bentuk independen umum artinya aku. Kata ini digunakan sebagai formula untuk memperkenalkan Allah (Kel 20:2). ${ }^{46}$

Kata eloheka adalah bentuk kata benda jamak maskulin akhiran orang kedua tunggal maskulin. ${ }^{47}$ Kata ini sering menunjuk kepada Allah yang benar (Kej. l:1) dan sering dipasangkan dengan nama Allah yang memang unik Yehovah (Kej. 2:4; Mzm. 100:3). Ketika kata ini menunjuk kepada Allah secara umum, itu menyampaikan dalam Alkitab bahwa Allah adalah pencipta, raja, hakim, Tuhan, dan juruselamat. KarakterNya adalah berbelas kasihan dan setia pada perjanjian-Nya. ${ }^{48}$

Kata el qanna diterjemahkan am a jealous God, yang dalam bahasa Indonesia diterjemahkan "adalah Allah yang cemburu". Kata el adalah bentuk kata benda tunggal maskulin, yang diterjemahkan Allah. Arti kata ini menunjuk kepada Allah, Allah yang perkasa, pahlawan. Ini adalah salah satu istilah yang paling kuno untuk Allah, allah, atau dewa. ${ }^{49}$ Kata qanna adalah bentuk kata sifat tunggal maskulin yang diterjemahkan jealous. ${ }^{50}$ Dalam setiap contoh, kata ini digunakan untuk menggambarkan karakter Allah. Dia adalah Allah yang cemburu yang tidak akan membiarkan penyembahan kepada allah yang lain. Kata ini selalu digunakan untuk menggambarkan sikap Allah terhadap penyembahan berhala, yang membangkitkan cemburu itu dan kemarahan dalam menghukum penyembah berhala (Ul. 4:24; 16:5). Begitu erat adalah sifat ini terkait dengan nama Allah sendiri yang namanya cemburu (Kel. 34:14). ${ }^{51}$ Kata "jealous" adalah kata yang sama yang diterjemahkan "zeal" atau "zealous". Kata ini menggambarkan gairah yang hebat untuk melindungi atau mempertahankan sesuatu yang membahayakan. Kegairahan Allah atau kecemburuan-Nya adalah untuk melindungi umat-Nya atau lembaga-Nya atau kehormatan-Nya. ${ }^{52}$ Kata ini tidak dipakai dalam arti atau implikasi yang jelek. ${ }^{53}$ Alasan larangan menyembah berhala oleh karena Allah adalah subjek penyembahan itu dan realitasnya sebagai Allah yang cemburu. Karena itulah manusia

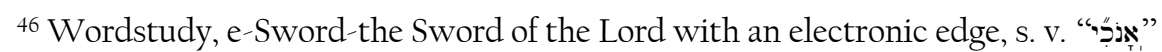

47 (WTM Morphology, Word Analysis, In Bible Works Version 7), s.v. "אלהֶיץ"

48 Wordstudy, e-Sword-the Sword of the Lord with an electronic edge, s. v. "אליהֶיר"

${ }^{49}$ Wordstudy, e-Sword-the Sword of the Lord with an electronic edge, s. v. "אל"

50 (WTM Morphology, Word Analysis, In Bible Works Version 7), s.v. " "קָָּ"

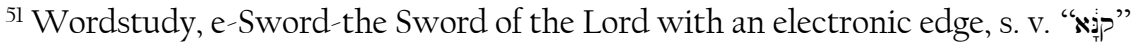

${ }^{52}$ Text footnotes for NET Version, Word Analysis In Bible Works Version 7

${ }^{53}$ Robert M.Patterson,Tafsiran Alkitab Kitab Keluaran (Jakarta: BPK Gunung Mulia, 2006), 6 .
} 
dilarang untuk mencoba merepresentasikan berhala apapun yang kelihatan, apakah dibuat dengan keahlian seniman atau pemahat. ${ }^{54}$

Kata poqed awon abot al-banimi yang diterjemahkan visiting the iniquity of the fathers upon the children, yang dalam bahasa Indonesia diterjemahkan "yang membalaskan kesalahan bapa kepada anak-anaknya." Kata awon diterjemahkan kesalahan. Ini adalah satu dari empat kata utama yang menunjukkan dosa dalam Perjanjian Lama. Kata ini menunjukkan dosa khususnya yang jahat, karena kata ini sangat kuat menyampaikan gagasan yang memutar atau sengaja mensyesatkan. Kata Ibraninya berarti dosa atau pelanggaran dalam arti sadar, seperti ketika Daud terus sadar dari pelanggaran atau dosa (2 Sam. 22:24), Israel oleh pilihan mereka sendiri kembali melakukan dosa nenek moyangnya (Yes. 53:11), rasa bersalah ayah adalah sebuah frasa yang berulang dalam Perjanjian Lama (Kel. 20:5; 34:7). Kata ini juga dalam beberapa konteks menunjukkan hukuman yang dihasilkan dari dosa dan kesalahan kita. ${ }^{55}$

Kata abot diterjemahkan ayah. Arti kata ini adalah ayah, kepala rumah tangga, leluhur, kebajikan, dan hormat. Kata ini terutama digunakan untuk menunjuk kepada ayah jasmani. ${ }^{56}$ Kata al-banim diterjemahkan kepada anak-anaknya. ${ }^{57}$ Kata ini menunjuk kepada anakanak pada umumnya baik laki-laki dan perempuan, juga keturunan seperti cucu..$^{58}$

Kata poqed ini sulit untuk diterjemahkan. Sering diartikan "visiting," di sini mungkin menunjuk kepada "dealing with" dalam pengertian negatif atau "punishing," tetapi kata ini menjelaskan perhatian yang positif dalam Keluaran 13:19. Ketika digunakan untuk Tuhan, pengertian utamanya adalah Allah campur tangan dalam kehidupan umat-Nya baik untuk memberkati atau mengutuk. Beberapa mungkin secara sederhana menerjemahkan partisip di sini sebagai "punishing" anak-anak untuk kesalahan bapanya (bnd. Im. 18:25; Yes. 26:21; Yer. 29:32; 36:31) tetapi mungkin tidak cukup. Ayat ini bisa menyatakan bahwa mereka yang membenci Yahweh dan tidak menuruti perintah-Nya akan mengulangi kesalahan yang bapanya lakukan dan menderita karena itu. Ulangan 24:16 berkata bahwa setiap orang harus dihukum mati karena dosanya sendiri dan bukan karena dosa ayahnya (Ul. 7:10, Yeh. 18). Pola kesalahan bapa diulangi dari generasi ke generasi di sini perlu untuk diperhatikan lagi. Jika dosa dan kesalahan tidak sepenuhnya timbul pada satu generasi

\footnotetext{
${ }^{54}$ Arthur W. Pink, Gleanings In Exodus (Chicago: Moody Press, 1978), 162.

55 Wordstudy, e-Sword-the Sword of the Lord with an electronic edge, s. v. "פקר"

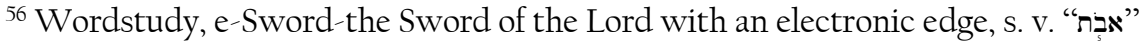

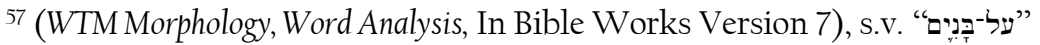

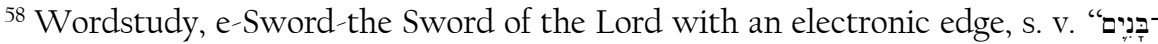


saja, maka tidak dapat dikendalikan mereka akan timbul dan berkelanjutan kemudian. Tetapi itu mungkin juga berarti bahwa pengaruh atau akibat dosa bapa akan dialami juga oleh generasi yang mengikutinya, lebih khusus dalam kasus Israel sebagai suatu bangsa (U. Cassuto, Exodus, 243). Di sini Allah menunjukkan bahwa karakter etika-Nya ditampilkan dalam bagaimana Ia berurusan dengan dosa dan kebenaran, semua yang Ia uraikan untuk memberi motivasi yang kuat agar setia kepada-Nya dan menghindari penyembahan berhala. Ada keadilan yang bekerja di dalam Allah yang tidak ada dalam dunia penyembahan berhala. ${ }^{59}$

Frasa al-sillesim weal-ribbeim lesonay yang diterjemahkan unto the third and fourth generation of them that hate me, yang dalam bahasa Indonesia diterjemahkan "kepada keturunan yang ketiga dan keempat dari orangorang yang membenci Aku." Kepada keturunan ketiga dan keempat ini adalah hukum dari pemerintahan Ilahi bahwa hukuman seseorang termasuk dengan mereka yang berhubungan dengannya (Yos. 22:20). ${ }^{60}$

Kata lesonay adalah bentuk kata kerja qal partisip jamak maskulin akhiran orang pertama tunggal dengan kata depan (le-) yang diterjemahkan yang membenci-Ku. ${ }^{61}$ Kata ini berarti membenci Allah atau orang lain; Allah menghukum anak-anak untuk dosa yang dilakukan ayah mereka untuk generasi ketiga dan keempat dari orangorang yang membenci Dia, tetapi menunjukkan kebaikan daripada hukuman terhadap orang yang mengasihi-Nya. Tuhan membenci sebagai musuh bagi orang yang mencintai kekejaman dan kejahatan, dan yang tidak berpegang pada perjanjian-Nya dan yang tidak setia kepada-Nya. ${ }^{62}$

Ini adalah kualifikasi penting dari prinsip. Kata yang berarti "menolak" ini sering diterjemahkan "membenci" dan mengandung ide penolakan dengan menantang dan menentang Allah dan firman-Nya. Orang-orang tersebut dihukum untuk melanjutkan dosa-dosa nenek moyangnya dan menanggung kesalahan yang sama. ${ }^{63}$

Dengan demikian ayat 5 ini melanjutkan penjelasan bagian hukum kedua yang mana ini merupakan lanjutan dari ayat 4 yaitu selain bangsa Israel dilarang membuat patung, mereka dengan tegas dilarang untuk menyembah atau beribadah kepada patung atau gambar atau berhala buatan itu. Dengan alasan yang jelas yakni keberadaan Allah sendiri bahwa Allah adalah Allah yang cemburu, yang tidak mengijinkan adanya

${ }^{59}$ Text footnotes for NET Version, Word Analysis In Bible Works Version 7.

${ }^{60} \mathrm{~J}$. R. Dummelow, A Commentary On The Whole Bible by Various Writers Complete In One Volume (New York: The Macmillan Company, 1923), 67.

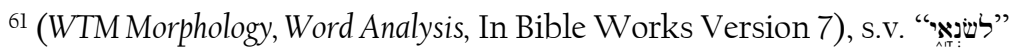

62 Wordstudy, e-Sword-the Sword of the Lord with an electronic edge, s. v. "לילניָאי "ל "

${ }^{63}$ Text footnotes for NET Version, Word Analysis In Bible Works Version 7. 
penyembahan atau peribadatan kepada berhala buatan manusia yang tidak mempunyai kuasa apa-apa sehingga Ia akan bertindak menghukum dengan membalaskan kesalahan, bukan hanya terhadap orang yang menyembah berhala, yang disebut sebagai orang yang membenci Allah, namun hukuman itu juga dirasakan oleh orang-orang yang berkaitan dengan orang tersebut, dan dalam jangka waktu yang panjang.

\section{Ayat 6}

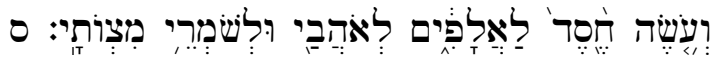

Kata waoseh, yang diterjemahkan shewing, dalam Bahasa Indonesia diterjemahkan menunjukkan. ${ }^{64}$ Kata khesed adalah bentuk kata benda tunggal maskulin yang diterjemahkan kasih setia. ${ }^{65}$ Kata ini menunjukkan kebaikan, kasih setia, rahmat, belas kasih, kesetiaan, cinta, dan tindakan kebaikan. Aspek Allah inilah yang merupakan satu hal penting dari karakter-Nya: kebenaran, kesetiaan, belas kasihan, keteguhan, keadilan. ${ }^{66}$

Secara harfiah oseh khesed berarti "doing loyal love". Kata benda tersebut menunjuk kepada kesetiaan Allah terhadap perjanjian-Nya, kasih setia-Nya kepada mereka yang menjadi milik-Nya. Merekalah anggota-anggota perjanjian, penerima kasih karunia, umat Allah, yang dipelihara dan dilindungi-Nya dari yang jahat dan pengaruhnya. ${ }^{67}$ Sebenarnya khesed yang diterjemahkan "kasih setia" di sini, adalah salah satu kata terbaik dalam Perjanjian Lama untuk kasih karunia dari Allah (grace). ${ }^{68}$

Kata laalapim berasal dari kata alapim adalah bentuk kata bilangan pokok jamak maskulin dengan kata depan (la-) yang diterjemahkan to thousands, yang dalam bahasa Indonesia diterjemahkan beribu-ribu. ${ }^{69}$ Setelah "tenth (kesepuluh)" Ibrani menggunakan bilangan pokok untuk bilangan tingkat juga. Pernyataan ini adalah lawan yang tepat dari kata sebelumnya. Kata "beribu-ribu" adalah mereka yang mengasihi Yahweh dan berpegang kepada perintah-Nya. Inilah keturunan dari orang benar, dan bahkan yang berhubungan dengan mereka, yang mendapatkan keuntungan dari kemurahan Allah. ${ }^{70}$

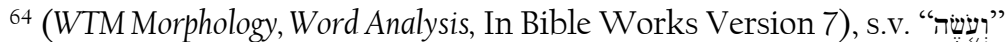

65 (WTM Morphology, Word Analysis, In Bible Works Version 7), s.v. " "רסח"

${ }^{66}$ Wordstudy, e-Sword-the Sword of the Lord with an electronic edge, s. v. "חקיח"

${ }^{67}$ Text footnotes for NET Version, Word Analysis In Bible Works Version 7

${ }^{68}$ Frank E. Gaebelein, The Expositor's Bible Commentary With The New Internasional Version Volume 2 (Grand Rapids, Michigan: Zoncervan Publishing House, 1990), 426.

69 (WTM Morphology, Word Analysis, In Bible Works Version 7), s.v. "לאירליה

${ }^{70}$ Text footnotes for NET Version, Word Analysis In Bible Works Version 7.
} 
Kata leohabai diterjemahkan dalam bahasa Indonesia mereka yang mengasihi-Ku. ${ }^{71}$ Dan miswotay diterjemahkan perintah-Ku. ${ }^{72}$ Dengan perbedaan yang kontras Dia adalah setia (menunjukkan kasih setia) kepada mereka yang mengasihi-Nya dan menunjukkan kesetiaan-Nya melalui ketaatan. ${ }^{73}$

Dengan demikian ayat 6 ini melengkapi bagian hukum kedua yang mana menunjukkan perbedaan yang jauh dan kontras antara hukuman yang diberikan bagi orang yang menyembah atau terlibat dalam penyembahan kepada patung berhala itu, dengan mereka yang kepadanya Allah menunjukkan kasih setia selama jangka waktu yang sangat panjang, karena memegang perjanjian dengan sungguh-sungguh mengasihi Allah dan menaati dan melakukan perintah-perintah-Nya.

\section{Makna Konteks Kecemburuan Allah Terhadap Penyembahan Berhala Berdasarkan Keluaran 20:4-6}

\section{Allah Tidak Dapat Direpresentasikan dalam Bentuk Apapun (20:4)}

"Jangan membuat bagimu patung yang menyerupai apa pun yang ada di langit di atas, atau yang ada di bumi di bawah, atau yang ada di dalam air di bawah bumi."

Berdasarkan analisis ayat di atas, maka yang menjadi makna konteks dari ayat 4 yaitu bahwa Allah tidak dapat direpresentasikan dalam bentuk apapun. Perintah kedua ini dengan tegas melarang usaha bangsa Israel untuk mencoba merepresentasikan Allah baik dalam bentuk yang ada di langit di atas, atau yang ada di bumi di bawah, atau yang ada di dalam air di bawah bumi. Hal itu jelas akan membawa bangsa Israel ke dalam penyembahan berhala. Ini sebenarnya berkaitan jelas dengan kepercayaan disekitar bangsa Israel yang menyembah berhala dan memiliki suatu bentuk kelihatan yang disembahnya. Bahkan kehidupan bangsa Israel sebelumnya di Mesir memberikan pengaruh yang besar akan kepercayaan-kepercayaan kepada berhala. Termasuk ketika mereka dalam hal ini sementara disiapkan Allah untuk menuju tanah perjanjian di mana daerah Kanaan pada waktu itu sangat erat dan kental akan penyembahan berhala. Itulah sebabnya sejak awal bangsa Israel diingatkan agar menyembah Allah saja dan tidak berusaha untuk merepresentasikan Allah, ataupun menyembah allah-allah lain sehingga mereka tidak akan terjebak dalam penyembahan berhala.

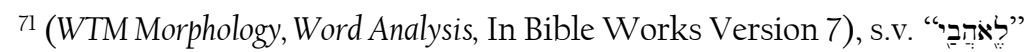

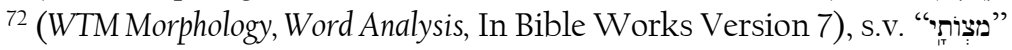

73 John F. Walvoord \& Roy B. Zuck, The Bible Knowledge Commentary an Expositon of the Scriptures by Dallas Seminary Faculty Old Testament (Wheaton, Illinois: Victor Books a division of SP Publication, Inc, 1986), 139. 
Berdasarkan arti kata, patung yang dimaksud bukan hanya patung yang dipahat atau dituang saja (graven image) tetapi gambarannya pun (idol) baik yang kelihatan maupun yang tidak kelihatan. Tafsiran Alkitab Masa Kini menuliskan bahwa perintah kedua ini ditujukan terhadap penyembahan berhala, dan bersifat umum, termasuk usaha menggambarkan Allah atau gambaran patung berhala makhluk-makhluk ciptaan. Hal-hal semacam itu merendahkan harkat Allah sebagai sang Pencipta dan makhluk ciptaan yang memuja mereka. Sementara kenyataan yang dilihat oleh bangsa Israel secara langsung di gunung Sinai bahwa tidak ada kelihatan bentuk atau keserupaan apapun dari Allah: hanya kedengaran suatu suara. ${ }^{74}$ Alasan kenapa dilarang yaitu karena memang tidak ada gambaran apapun yang dapat menggambarkan Allah. Charles John Ellicot menguraikan bahwa:

"Apa yang dilarang dalam hukum kedua adalah penyembahan kepada Allah dalam bentuk materi. Hal itu memaksakan ke-Ilahian Yehovah. Sementara hampir di seluruh dunia kuno, jarang ada satu bangsa atau suku yang tidak 'membuat bagi mereka' gambaran dari dewanya, dan menganggap gambaran itu sendiri sebagai takhyul penghormatan, dalam bangsa Yahudi sendiri ini adalah praktik yang dilarang. Tidak akan ada suatu kemiripan yang bisa dibuat dari Dia, tidak ada representasi apapun yang bisa menggambarkan konsep dari semua pemisahan atas keadaan, esensi spiritual-Nya. ${ }^{75}$

Oleh sebab itulah bangsa Israel dilarang untuk membuat patung (pesel). Sebagaimana dari kata pesel tersebut menunjukkan usaha manusia yang mencoba untuk membuat representasi dari Allah. Allah melarang bangsa Israel membuat berbagai bentuk pahatan untuk menggambarkan diri-Nya atau sebagai fokus pengganti diri-Nya. Karena tidak ada satupun yang dapat menyamai diri-Nya (Yes 40:25; 42:8). Patung-patung apapun yang dibuat tidak akan mencukupi gambaran eksistensi dan esensi diri-Nya.

Penjelasan dalam ayat 4b, "yang ada di langit di atas, atau yang ada di bumi di bawah, atau yang ada di dalam air di bawah bumi," tidak melarang perhiasanperhiasan pada umumnya, tetapi melarang usaha untuk mewakili Tuhan dalam bentuk seekor hewan, burung dan sebagainya. Perhiasanperhiasan demikian, sama seperti patung, menjadi sumber pencobaan yang besar. Bukan hanya sifat Tuhan yang salah dimengerti, tetapi orang mulai beribadah kepada allah-allah lain. Pencobaan demikian nyata bagi

${ }^{74}$ Tafsiran Alkitab Masa Kini 1 Kejadian-Ester (Jakarta: BPK Gunung Mulia untuk Yayasan Komunikasi Bina Kasih/OMF, 1982), 169.

75 Charles John Ellicott, Ellicott's Commentary On The Whole Bible A Verse By Verse Explanation (Grand Rapids, Michigan: Zondervan Publishing House, 1959), 260. 
orang Israel yang tinggal di tengah orang-orang Kanaan. Dengan mudah mereka percaya bahwa allah-allah orang Kanaan itu akan menjamin panen yang lebih baik jika mereka beribadah kepadanya. Namun tidak ada toleransi dari Tuhan terhadap allah-allah itu, sebab Dia adalah Allah mereka yang tunggal, satu-satu-Nya dan tidak membiarkan mereka mengikuti allah yang lain. Alasan ini jelas karena tidak ada gambaran apapun yang dapat menggambarkan atau menyamai atau merepresentasikan Allah.

Hukum ini menunjukkan bahwa Allah tidak bisa disembah di bawah bentuk dari setiap representasi materi apapun, apakah itu hasil dari plastik atau patung seni. Itu bukan hanya mengalihkan pikiran akan pengetahuan tentang ke-Ilahian Allah yang suci, tetapi tak dapat diragukan akan membuat diri mereka menjadi objek dari pemujaan itu dan juga menyebabkan naiknya praktik-praktik sensual. ${ }^{76}$ Tafsiran Wycliff menuliskan alasan dasar perintah ini adalah mengingatkan bahwa Allah adalah Roh sehingga tidak dapat dipahami sebagai yang dibuat menurut rupa manusia ataupun menurut rupa suatu makhluk ciptaan lain. ${ }^{77}$ Keberadaan-Nya sebagai Roh merupakan inti mengapa Allah tidak dapat direpresentasikan dan menjelaskan bagaimana seharusnya menyembah Allah yaitu menyembah Dia dalam Roh bukan dalam materi representasi apapun. Tidak seorang pun yang dapat memahami dengan sempurna tentang kesempurnaan Allah ataupun dapat menggambarkan satu pun kemiripan-Nya.

\section{Tidak Boleh Ada Objek Penyembahan Yang Lain Selain Allah (Ayat 5a) \\ "Jangan sujud menyembah kepadanya atau beribadah kepadanya"}

Hukum Kedua ini secara khusus ditujukan kepada penyembahan yang harus diberikan kepada Allah. Jangan sujud menyembah kepadanya dan beribadah kepadanya menyatakan larangan bahwa tidak boleh menyembah allah lain dalam bentuk apapun. Karena memang berhala bukan objek penyembahan itu. Justru penyembahan harus ditujukan kepada Allah. Objek penyembahan adalah Allah sendiri. Dengan kenyataan bahwa Allah adalah Allah yang cemburu.

Penyembahan kepada allah asing tidak dapat diterima. Menyembah kepada Allah harus dilakukan langsung kepada Allah tanpa objek apapun baik patung ataupun gambaran lainnya. Hukum ini terkait dengan patung yang dibuat dengan tujuan untuk disembah, sebuah berhala untuk dimuliakan, dan bukan patung-patung biasa. Carl Barth

${ }^{76}$ F. Davidson, A. M. Stibbs, E. F. Kevan, The New Bible Commentary (Grand Rapids, Michigan: WM. B. Eerdmans Publishing Company, 1965), 120.

77 Charles F. Pfeiffer dan Everett F. Harrison, Tafsiran Alkitab Wycliffe, Volume 1 Perjanjian Lama: Kejadian-Ester (Malang: Gandum Mas, 2004), 202. 
menuliskan bahwa bukan hanya pembuatan patung-patung yang menggambarkan allah-allah asing di samping Allah saja yang terlarang, melainkan membuat dan mendirikan patung yang menggambarkan Allah sendiri. Sebagaimana Hukum Pertama melarang ibadat kepada allah kecuali kepada Tuhan sendiri, Hukum Kedua ini melarang cara beribadah kepada Tuhan, di mana kehadiran-Nya dijamin dengan perantaraan sebuah patung. ${ }^{78}$

Maka hukum ini dengan tegas melarang orang Israel beribadah kepada Tuhan dengan cara yang tidak sesuai dengan sifat-Nya. Karena pada zaman kuno patung dianggap sebagai tempat berdiamnya allah yang diwakilinya. ${ }^{79}$ Itu berarti bahwa allah itu bersifat statis dan terbatas, bahkan bisa dikontrol oleh orang yang beribadah kepadanya. Namun, Tuhan bersifat dinamis, bebas dan tidak terbatas. Dialah yang memerintah dan tidak dapat dikontrol. Patung-patung cenderung menarik minat manusia sehingga dia beribadah kepada Tuhan seakan sifat-Nya sama dengan sifat allah-allah kafir. Tanpa patung, manusia lebih terbuka terhadap Tuhan dan mengenal sifat-Nya yang sesungguhnya.

Menarik melihat keadaan agama dan penyembahan disekitar bangsa Israel yang menunjukkan bahwa mereka menggunakan objek tertentu sebagai simbol allah atau kekuatan lain untuk disembah. John F. Walvoord \& Roy B. Zuck menuliskan bahwa baik di Mesir dan Kanaan, manusia dan hewan memainkan peran yang penting dalam penggambaran atribut dari berhala. Setiap usaha dari Israel untuk merepresentasikan Allah dengan menggunakan patung-patung akan menghasilkan penyimpangan gambaran atas natur asli-Nya. ${ }^{80}$ Dengan demikian bangsa Israel diperingatkan untuk tidak menyembah allah lain seperti yang dilakukan oleh kepercayaan-kepercayaan di sekeliling bangsa Israel karena nantinya akan membawa mereka ke dalam penyembahan berhala. Walaupun dalam sejarah bangsa Israel kemudian diketahui bahwa merekapun justru mengikuti penyembahanpenyembahan kepada berhala dan juga membuat representasi Allah melalui patung lembu emas.

Charles John Ellicot menjelaskan bahwa: "Penyembahan berhala pada jaman kuno dahulu, pada kenyataannya, bukan sekedar ibadah kepada makhluk-makhluk celestikal melalui gambarannya, tetapi menjadi budaya terhadap gambar-gambar itu sendiri, yang dianggap

\footnotetext{
${ }^{78}$ C. Barth, Teologia Perjanjian Lama Jilid Pertama (Jakarta: BPK Gunung Mulia, 1991), 317.

${ }^{79}$ Robert Paterson, Kitab Keluaran (Jakarta: Bpk Gunung Mulia, 2006), 266.

${ }^{80}$ John F. Walvoord \& Roy B. Zuck, The Bible Knowledge Commentary an Expositon of the Scriptures by Dallas Seminary Faculty Old Testament (Wheaton, Illinois: Victor Books a division of SP Publication, Inc, 1986), 107.
} 
memiliki kekuatan ajaib..$^{81}$ Jadi, penyembahan kepada objek yang lain selain Allah seperti menyatakan bahwa ada kekuatan lain yang menyamai ataupun lebih besar dari Allah. Itulah sebabnya bangsa Israel dilarang dengan keras untuk menyembah objek yang lain selain Allah. Allah ingin menyatakan bahwa tidak ada satupun kekuasaan yang menyamai-Nya.

Salah satu kebenaran rohani yang paling berharga adalah dilambangkan dalam kenyataan ketika seseorang menembus ke rahasia inti tabernakel, pada tabut Hukum di dalam ruang Maha Kudus, orang itu menemukan bahwa di dalam-Nya kosong. Tidak ada patung atau gambar Yahweh yang dapat dibuat. ${ }^{82}$ Manusia diciptakan sesuai dengan gambar Allah. Maka usaha manusia untuk membuat gambar/patung adalah sama dengan mencoba menciptakan Allah sendiri. Hal ini jelas merupakan pelanggaran dalam Hukum Kedua.

\section{Penyembahan Kepada Berhala Mendatangkan Kecemburuan Allah (20:5b)}

"sebab Aku, TUHAN, Allahmu, adalah Allahyang cemburu"

Salah satu kebenaran yang berharga yang untuk pertama kalinya muncul dalam Alkitab adalah pernyataan Allah bahwa Ia adalah Allah yang cemburu. Hal yang menarik adalah pernyataan ini secara langsung diberikan bersamaan dengan pernyataan Hukum Allah. Kecemburuan Allah dijelaskan muncul sebagai akibat dari penyembahan berhala. Walter Kaiser mengatakan bahwa semua penyembahan berhala akan memunculkan lawan atau perlawanan terhadap kehormatan dan kemuliaan Allah dan akan menggerakkan kecemburuan-Nya oleh karena karakter dan keberadaan-Nya. ${ }^{83}$

Dalam bagian inilah untuk pertama kalinya kecemburuan Allah disampaikan. Begitu tegasnya perintah ini sehingga pernyataan bahwa Allah, yang membebaskan bangsa Israel dengan kuasa ajaib-Nya adalah Allah yang cemburu. YHWH memperkenalkan diri-Nya sebagai "Allahmu," yang menunjukkan adanya hubungan khusus antara Israel dan Allah. Hubungan ini sering disebut dengan hubungan perkawinan. Allah Israel tersebut adalah Allah yang cemburu, artinya Allah yang tidak mengizinkan adanya perselingkuhan umat-Nya dengan ilah apapun. Penyembahan kepada Allah dengan cara yang tidak sesuai

${ }^{81}$ Charles John Ellicott, Ellicott's Commentary On The Whole Bible A Verse By Verse Explanation (Grand Rapids, Michigan: Zondervan Publishing House, 1959), 260.

82 George Arthur Buttrick, The Interpreter's Bible The Holy Scriptures Volume I General And Old Testament Articles Genesis-Exodus (Nashville: New York Abingdon Press, 1952), 982.

${ }^{83}$ Frank E. Gaebelein, The Expositor's Bible Commentary with The New International Version Volume 2 (Grand Rapids, Michigan: Zondervan Publishing House, 1990), 423. 
dengan kehendak-Nya bukanlah penyembahan kepada Allah yang benar sehingga penyembahan itu sendiri berpotensi menjadi penyembahan berhala. ${ }^{84}$ Perintah ini begitu serius. Matthew Henry menjelaskan bahwa kecemburuan Allah ini jelas berbeda dengan cemburu manusia karena kecemburuan Allah menandakan suatu emosi yang positif untuk melindungi apa yang menjadi milik-Nya. ${ }^{85}$ Dengan perjanjian yang dibuat di gunung Sinai ini maka Israel menjadi milik Allah. Untuk menjaga milik Allah inilah, Allah dikatakan sebagai Allah yang cemburu. Kecemburuan Allah ini berkaitan tentang sesuatu yang menjadi milikNya, apa yang seharusnya hanya diberikan kepada-Nya.

Matthew Henry menulis bahwa kecemburuan Allah adalah dalam hal penyembahan. Itu menandakan bagaimana dengan sangat intim Ia peduli terhadap ciptaan-Nya, Ia tidak setuju terhadap penyembah berhala dan semua penyembahan yang tidak benar, Ia tersinggung terhadap para penyembah berhala, dan bahwa Ia membenci setiap hal dalam penyembahan yang kelihatan atau mengarah kepada penyembahan berhala. Ketidaksenangan Allah melawan hal itu cocok disebut cemburu. ${ }^{86}$ Itulah mengapa Allah mendeklarasikan bahwa Ia adalah Allah yang cemburu. Penyembahan kepada Allah adalah menjadi milik Allah sendiri. Hal ini juga menjelaskan kenapa Allah tidak dapat direpresentasikan. Yehovah adalah Allah yang tidak dapat disalin karena Dia menyatakan sifat rohani-Nya dalam bentuk yang tidak terlihat. Jika Ia disembah melalui beberapa gambar yang kelihatan, kemuliaan Allah yang tidak kelihatan itu berubah, atau Yehovah berubah menjadi Allah yang berbeda dari Allah yang sesungguhnya. Oleh karena bentuk penyembahan berhala itulah Israel akan merusakkan perjanjian-Nya dengan Allah. ${ }^{87}$

Kecemburuan Allah menjadi landasan atau alasan bagi Hukum Kedua ini. Membuat atau mendirikan patung itu berarti mau menguasai Allah, mau menjamin kehadiran-Nya sebagai Allah Israel, padahal Ia bebas dan berdaulat untuk menyatakan diri-Nya hadir menurut kesukaan-Nya sendiri. Jadi, kecemburuan Allah bukan dalam pengertian bahwa Ia iri hati akan kesuksesan atau kebahagiaan orang lain, tetapi bahwa Ia sendirilah yang punya klaim atas cinta dari umat-Nya. Hal ini

84 Studi Alkitab. Hukum Taurat: Hukum Kedua, diakses 8 Mei 2014, http://www.studialkitab.com/2010/04/hukum-taurat-hukum-ke-2.html.

${ }^{85}$ Matthew Henry \& Thomas Scott, Commentary On The Holy Bible With Explanatory

Notes From Other Writers Genesis - Esther (Nashville, New York: Thomas Nelson Publishers, 1798), 181.

${ }^{86} \mathrm{Ibid}$.

${ }^{87}$ C. F. Keil and F. Delitzsch, Commentary On The Old Testament In Ten Volumes Volume I The Pentateukh (Grand Rapids, Michigan: William B. Eerdmans Publishing Company, 1975), 118. 
untuk umat-Nya juga, supaya mereka menguduskan dan menghormati nama-Nya, bahwa mereka harus menjauhkan diri dari penyembahan berhala. Kecemburuan Allah melindungi kemurnian penyembahan umatNya. ${ }^{88}$ Sejak awal Israel dilarang untuk menyembah allah apapun selain Allah karena Allah yang cemburu tidak membiarkan adanya saingan. Allah cemburu sebab Dia mempertahankan hak-Nya sebagai satusatunya yang disembah. Penyembahan berhala mengalihkan fokus umat Israel akan relasi khususnya dengan Allah yang sangat indah dengan sesuatu yang terbatas pada apa yang kelihatan saja.

Kecemburuan Allah ini bagaimanapun juga, adalah prinsip perlindungan Allah atas umat-Nya. Kecemburuan Allah dinyatakan dalam dua arah. Di satu sisi, dipicu oleh penyembahan berhala, yang merupakan perebutan hak istimewa Allah (Ul. 32:16, 21, Mzm. 75:58), atau oleh ketidaktaatan, termasuk tidak mengindahkan komitment (Ul. 4:24, 1 Raj. 14:22. Tetapi Allah juga cemburu karena kekudusan-Nya (Yos. 24:19; Yeh. 39:25). Perjanjian kecemburuan menuntut ketaatan total kepada Allah, yang nama-Nya adalah cemburu.

\section{Kecemburuan Allah Atas Penyembahan Berhala Mendatangkan Hukuman (20:5c)}

".yang membalaskan kesalahan bapa kepada anak-anaknya, kepada keturunan yang ketiga dan keempat dari orang-orang yang membenci Aku."

Bukan saja tidak ada gambaran apapun yang menyerupai diri-Nya, Dia bahkan adalah Allah yang cemburu terhadap mereka yang menduakan diri-Nya, sehingga Dia akan bertindak dan menghukum. Penyembahan berhala selalu mendatangkan hukuman. Hukuman yang dimaksud adalah membalaskan kejahatan. Membalaskan kejahatan ini adalah dalam konteks hubungan perjanjian. Hal inilah yang dialami oleh bangsa Israel sebagai akibat akan penyembahan berhala. Begitu seriusnya hukum ini dan oleh sebab itulah dengan tegas Allah sejak awal memperingatkan bangsa Israel akan hal ini. Matthew Henry menuliskan, "Penyembahan berhala adalah pelanggaran perjanjian nasional yang dibuat dengan Israel, dan mengorbankan perjanjian berkat sehingga anak cucu mereka akan menderita oleh karena dosa-dosanya." 89

Hukuman akibat dosa karena penyembahan berhala sangat tegas: membalaskan kesalahan bapa kepada anak-anaknya, kepada keturunan yang ketiga dan keempat dari orang-orang yang membenci Aku. Kata "membalas" menjelaskan bahwa Allah tidak pernah mengabaikan atau

${ }^{88}$ F. Davidson, A. M. Stibbs, E. F. Kevan, The New Bible Commentary (Grand Rapids, Michigan: WM. B. Eerdmans Publishing Company, 1965), 120.

${ }^{89}$ Matthew Henry \& Thomas Scott, Commentary On The Holy Bible With Explanatory Notes From Other Writers Genesis - Esther (Nashville, New York: Thomas Nelson Publishers, 1798), 181. 
melupakan dosa meskipun dosa itu sudah dilakukan beberapa waktu yang lalu. Allah akan memberikan ganjaran kepada dosa. Hukuman atas penyembahan berhala jelas. Menghukum yakni membalaskan kesalahan bapa kepada anaknya sampai keturunan ketiga dan keempat. Ini menyatakan hukuman akan dialami bukan hanya sampai pada generasi itu saja melainkan sampai keturunan ketiga dan keempat. Pernyataan "kesalahan bapa kepada anak" adalah sistem atau konsep penyembahan yang bersifat "diturunkan." Artinya cara penyembahan orang tua yang salah akan diteruskan oleh anak cucunya kemudian. Kesalahan orang tua akan menjadi model bagi anak untuk melakukan hal yang sama di waktu yang akan datang. ${ }^{90}$

C. F. Keil and F. Delitzsch menulis bahwa hal ini sangat jelas bahwa anak-anak menderita konsekuensi dari dosa orang tua mereka. Allah menyatakan bahwa akan jadi seperti demikian, sama seperti kasih sayang yang secara alami kita berikan kepada anak-anak, dan juga untuk menahan kita dari kejahatan. Allah menghukum dosa bapa-bapa kepada anaknya sampai generasi ketiga dan keempat dalam hubungannya dengan mereka yang membenci-Nya, dan menunjukkan kasih setia kepada beribu-ribu generasi dalam hubungannya dengan mereka yang mengasihi-Nya. Umat manusia adalah organisme yang hidup, di mana bukan hanya dosa dan kejahatan saja yang terlihat, tetapi juga kejahatan sebagai kutukan dosa dan hukuman dari kejahatan. Sebagaimana anakanak menerima sifat-sifatnya dari orangtua, atau yang melahirkan mereka, maka mereka juga harus menanggung dan menebus kesalahan ayahnya. ${ }^{11}$ F. Davidson menjelaskan bahwa,

Sangat jelas bahwa Allah tidak menghukum anak-anak karena melawan orangtuanya, tetapi jika anak-anak komit dosa yang sama seperti yang ayahnya lakukan maka mereka akan dihukum dengan cara yang sama (mereka yang membenci-Ku) juga dosa-dosa orangtua memengaruhi anakanak mereka terhadap yang jahat dan membawa hukuman dosa tertentu yang mau tidak mau dirasakan bersama oleh keturunannya misalnya penyakit yang diakibatkan oleh imoralitas dan kemiskinan yang diakibatkan oleh pemborosan. Tetapi pengaruh rohani jauh lebih dalam lagi. Setiap jenis takhayul di sini di larang - penggunaan sesuatu yang hanyalah ciptaan manusia untuk menyembah Allah, sebagaimana jika itu penting dalam ibadah atau diterima oleh dia. Semua kemunafikan atau formalitas, yang muncul dari pengertian yang tidak benar tentang Allah,

90 Studi Alkitab. Hukum Taurat: Hukum Kedua, diakses 8 Mei 2014, http://www.studialkitab.com/2010/04/hukum-taurat-hukum-ke2.html

${ }^{91}$ C. F. Keil and F. Delitzsch, Commentary On The Old Testament In Ten Volumes Volume I The Pentateukh (Grand Rapids, Michigan: William B. Eerdmans Publishing Company, 1975), 118. 
adalah pelanggaran terhadap Hukum ini dan semua penggambaran Alkitabiah dari karakter Ilahi. ${ }^{92}$

Penyembahan berhala selalu mendatangkan hukuman yang serius. Sebagaimana Allah menghargai Israel sebagai kepunyaan-Nya, kecemburuan-Nya akan mendatangkan hukuman bagi mereka yang menyembah berhala.

\section{Kecemburuan Allah Menyatakan Bahwa Allah Mengasihi Umat-Nya (20:6)}

"Tetapi Aku menunjukkan kasih setia kepada beribu-ribu orang, yaitu mereka yang mengasihi Aku dan yang berpegang pada perintah-perintah-Ku."

Bukti kasih Allah bagi bangsa Israel dinyatakan melalui kecemburuan-Nya. Kecemburuan Allah ini sejalan dengan kasih dan bukan berlawanan dengan kasih. Alasan mengapa Allah cemburu adalah karena Ia ingin manusia memilih untuk mengasihi-Nya. Dalam Hukum ini, Allah menginginkan bangsa Israel untuk mengasihi-Nya bukan menyembah berhala. Bahasa ini keras tetapi sangat berhubungan dengan kasih Allah. Sebenarnya hubungan perjanjian itu adalah karena kasih. Peter Craige menulis bahwa salah satu hubungan perjanjian yang dibuat Allah dengan bangsa Israel adalah hubungan kasih. Kasih diprakarsai oleh Allah dalam perjanjian-Nya dan juga menuntut respon kasih dari bangsa Israel. ${ }^{93}$ Allah yang berinisiatif untuk membuat perjanjian dan sebaliknya menuntut respons kasih dari bangsa Israel. Gagasan mengenai berhala menyatakan bahwa jangan sampai Israel melupakan kasih Allah yang dinyatakan melalui pembebasan mereka dari Mesir (20:2).

Allah mengasihi bangsa Israel sebagai umat-Nya. C. F. Keil dan F. Delitzsch menjelaskan dengan baik: "Jika Allah terus untuk waktu yang lama, menghukum dosa, Dia juga akan terus sampai selamanya, menunjukkan kasih setia-Nya, dan kita tidak bisa memiliki bukti yang lebih baik selain dalam sejarah bangsa Israel itu sendiri." 94 Perjalanan hidup bangsa Israel menjadi bukti bagaimana Allah setia dengan perjanjian-Nya.

${ }^{92}$ F. Davidson, The New Bible Commentary (Grand Rapids: WM. B. Eerdmans Publishing Company, 1965), 120.

93 P. C. Craigie, The New International Commentary on the Old testament, The Book of Deuteronomy.(Grand Rapids Michigan: William B. Eerdmans Publishing Company, 1979),

${ }^{94}$ C. F. Keil and F. Delitzsch, Commentary On The Old Testament In Ten Volumes Volume I The Pentateukh (Grand Rapids, Michigan: William B. Eerdmans Publishing Company, 1975), 118. 
Sebagaimana Hukum diberikan dengan adanya hukuman bagi yang melanggar maka kasih setia Tuhan menjadi berkat bagi mereka yang setia. Itulah sebabnya ditulis "yaitu mereka yang mengasihi Aku dan yang berpegang pada perintah-perintah-Ku" Jadi, ada hubungan kasih yang timbal balik antara Allah dan bangsa Israel. Bukan hanya Allah saja yang mengasihi namun bangsa Israel pun harus mengasihi Allah. Herbert Wolf menuliskan bahwa kata kasih (hesed) itu menyatakan loyalitas kepada hubungan perjanjian itu dan kepada janji-janji yang sudah dibuat-Nya. Israel didesak untuk tidak melupakan perjanjian yang sedang mereka buat, atau Allah akan menghukum mereka dan mengusir mereka dari tanah perjanjian itu. ${ }^{95}$

Lebih dalam lagi frasa "kasih setia" (khesed) memiliki padanan makna dengan dua kata yaitu 'perjanjian' dan 'kesetiaan'. Sehingga makna dari frasa "kasih setia" dapat dijelaskan sebagai 'kasih yang mantap teguh atas dasar perjanjian yang telah dibuat'. Arti ini digunakan untuk menggambarkan baik sikap Allah terhadap umat-Nya maupun sikap umat Allah terhadap Dia.

Oleh karena itu, kasih Allah ini juga menuntut kasih umat-Nya. Harus ada timbal balik: Allah mengasihi dan sebaliknya umat Israel harus mengasihi Allah juga. Allah tegas terhadap dosa tetapi lebih dari itu mata-Nya tidak akan melewatkan orang-orang yang mengasihi dan berpegang pada perintahNya. "yaitu mereka yang mengasihi Aku dan yang berpegang pada perintah-perintah-Ku" Bentuk kalimat pernyataan ini menyatakan bahwa kasih kepada Allah diwujudnyatakan dengan melakukan perintah-perintah Tuhan. Keduanya tidak dapat dipisahkan. Sehingga hal ini kembali menegaskan tentang semangat bangsa Israel untuk melakukan firman Tuhan adalah kasih.

Kecemburuan Allah mendorong umat-Nya untuk tetap setia dan lebih menunjukkan kasih sebagaimana dasar kecemburuan Allah sendiri adalah kasih bagi umat-Nya yang adalah milik-Nya. Kasih Allah inilah yang kemudian harus menjadi dasar bagi bangsa Israel untuk menaati dan melakukan segala hukum yang diberikan Allah. John Calvin menulis, "Sumber dan asal-usul dari kebenaran sejati diungkapkan, sebab ketaatan lahiriah terhadap hukum Taurat tidak ada gunanya terkecuali jika ketaatan itu bersumber dari kasih kepada Allah." ${ }^{96}$

\section{Implikasi Teologis Kecemburuan Allah Terhadap Penyembahan Berhala Berdasarkan Keluaran 20:4-6}

${ }^{95}$ Herbert Wolf, Pengenalan Pentateukh (Malang: Penerbit Gandum Mas, 1998), 35.

96 Charles F. Pfeiffer dan Everett F. Harrison, Tafsiran Alkitab Wycliffe, Volume 1 Perjanjian Lama: Kejadian-Ester (Malang: Gandum Mas, 2004), 203. 


\section{Kecemburuan Allah Terhadap Penyembahan Berhala Menyatakan Kekudusan Allah}

Kecemburuan Allah selalu berada dalam konteks adanya penyembahan kepada dewa-dewa atau berhala, atau dengan kata lain dalam konteks adanya penyembahan selain kepada Allah yang sesungguhnya, yang memperkenalkan diri-Nya sebagai "AKU ADALAH AKU" kepada Musa. Nama ini menunjuk kepada apa adanya Allah dalam diri-Nya, bahwa Dia sepenuhnya eksisten dalan diri-Nya sendiri, cukup dalam diri-Nya sendiri, dan kekal. ${ }^{97}$ Allah yang sejati merujuk kepada Allah yang kudus. Nizzim Amzallag menyatakan bahwa kecemburuan Allah ini menekankan atribut penting Yahweh yaitu kekudusan-Nya. ${ }^{98}$

Kekudusan merupakan natur Allah yang membedakan Allah dari segala sesuatu yang lain dan juga merupakan karakteristik Allah yang memisahkan Dia dari ciptaan-Nya. Kekudusan berkenaan dengan transendensi-Nya. ${ }^{99}$ Dari semua sifat Allah, kekudusan adalah satusatunya yang paling unik yang menggambarkan Dia dan dalam kenyataan adalah ringkasan dari semua sifat-Nya yang lain. Hal ini menunjukkan kesempurnaan-Nya yang lengkap tanpa batas. Kenyataan inilah yang akan benar-benar mengubah mutu penyembahan itu.

Oleh karena itu, untuk berada dalam hubungan perjanjian dengan Allah, bangsa Israel harus kudus. Itulah mengapa Allah memerintahkan untuk tidak menyembah allah lain, bahkan menyembah-Nya dengan cara yang tidak layak (membuat patung) adalah pelanggaran. Kekudusan Allah terlihat paling nyata dalam kebencian-Nya akan dosa dan penghukuman terhadap dosa. Perintah Kedua ini menunjukkan hal tersebut. John Mac Arthur menulis dalam bukunya Prioritas Utama Dalam Penyembahan bahwa salah satu dari alasan-alasan utama Allah membuat Hukum Taurat melalui Musa adalah untuk menunjukkan kekudusanNya. ${ }^{100}$ Kekudusan Allah menunjukkan bahwa tidak ada yang dapat menyamai-Nya (Yes. 40:25). Kedudukan atau posisi Allah tak tergantikan oleh siapapun dan oleh apapun. Segala usaha yang dilakukan manusia untuk menyamakan Allah dengan sesuatu yang lain yang merupakan ciptaan-Nya, berarti merendahkan Allah. Untuk itulah hukum ini diberikan.

${ }^{97}$ James Montgomery Boice, Dasar-Dasar Iman Kristen. (Surabaya: Momentum, 2011), 102.

${ }^{98}$ Nizzim Amzallag, "Furnace Remelting as the Expression of YHWH's Holiness: Evidence from the Meaning of qanna (קנא ) in the Divine Context" Journal of Biblical Literature. Vol. 134 No. 2 (2015): 233.

${ }^{99}$ Ibid. 132.

100 John Mac Arthur, JR. Prioritas Dalam Penyembahan (Bandung: Kalam Hidup, 1983), 100. 
Melalui Hukum ini Allah telah mengangkat Israel menjadi umat milik-Nya, terutama perbuatan inilah yang mengasingkan dan memisahkan Dia dari segala kekuatan yang disebut allah, dan perbuatan ini pula yang mengasingkan bangsa Israel dari segala bangsa lain. Allah cemburu berarti bahwa Ia penuh dengan gairah untuk mempertahankan milik-Nya, untuk tidak membaginya dengan kuat kuasa manapun juga. Penyerahan diri yang total dari pihak Tuhan menghendaki suatu penyerahan yang tidak kurang totalnya dari pihak umat-Nya. Nyala gairah dan tekad bulat inilah yang dengan nama lain disebut kekudusan (bnd. Yos. 24:19). Jelaslah bahwa dengan larangan ini Allah menguduskan umat-Nya.

Sayangnya, dalam perjalanan sejarah kehidupan bangsa Israel kemudian membuktikan mereka seringkali mereka melupakan Allah dan kekudusan-Nya. Bangsa Israel menggantikan posisi Allah dengan yang bukan Allah. Mereka menggantikan peribadahan dan penyembahan yang seharusnya hanya kepada Allah dengan peribadahan dan penyembahan kepada dewa-dewa atau berhala bangsa Kanaan. Hal ini tidak berkenan kepada Allah dan membangkitkan kecemburuan-Nya. Itulah sebabnya sejak awal perjalanan mereka sebagai umat Allah, Allah telah memperingatkan terlebih dahulu agar mereka tidak terpengaruh untuk membuat dan menyembah patung.

\section{Kecemburuan Allah Terhadap Penyembahan Berhala Menyatakan Kesetiaan Allah}

Perbuatan Allah bagi bangsa Israel dalam sejarah membuktikan konsistensi dan kesetiaan Allah. Sejak pemilihan dan panggilan Allah kepada Abraham, pemberian janji kepada Abraham, pemilihan Ishak dan Yakub, peristiwa keluarnya bangsa Israel dari Mesir, sampai kepada pendudukan bangsa Israel atas tanah Kanaan, semuanya dikerjakan Allah dalam kesetiaan-Nya. Kesetiaan Allah berarti Ia ternyata benar, ${ }^{101}$ dan kesetiaan-Nya membuat Ia menepati semua janji-Nya, baik yang telah diucapkan-Nya maupun yang tersirat di dalam hukum-hukum yang Ia berikan. ${ }^{102}$ Jadi oleh kesetiaan Allah maka segala perkataan, janjijanji dan rancangan-Nya adalah benar dan pasti digenapi-Nya.

Allah setia kepada umat kepunyaan-Nya, yaitu Israel, yang telah dipilih dan ditetapkan oleh Allah menjadi milik-Nya. Allah memegang dan menepati perjanjian yang dibuat-Nya dengan bangsa Israel (Ul. 7:9). Maka, maksud Allah memberi tahu Israel bahwa Ia adalah Allah yang cemburu adalah Allah menuntut kesetiaan yang absolut dan tertinggi dari orang yang Ia kasihi dan tebus, serta akan mempertahankan

${ }^{101}$ Millard J. Erickson, Teologi Kristen Vol. l. (Malang: Gandum Mas, 2004), 466.

102 Henry C. Thiessen, Teologi Sistematika. (Malang: Gandum Mas, 2010), 134. 
pernyataan-Nya dengan tindakan yang tegas jika mereka mengkhianati kasih-Nya dengan ketidaksetiaan.

Dengan demikian, kecemburuan Allah menyatakan kesetiaan-Nya dan sekaligus menunjukkan tuntutan-Nya akan kesetiaan. Allah yang setia menghendaki umat yang setia kepada-Nya. Allah menghendaki umat yang memegang perkataan dan menepati janji yang telah mereka buat. Pengingkaran terhadap janji yang mereka buat di hadapan Tuhan inilah yang akan mengakibatkan cemburu Tuhan menyala atas mereka (Ul. 29:20).

\section{Penyembahan Berhala Merupakan Perzinaan Rohani}

Perjanjian Lama memandang perjanjian Allah sebagai pernikahanNya dengan bangsa Israel. ${ }^{103}$ Frasa "Allah yang cemburu" kemungkinan diambil dari hubungan pernikahan yang sering digunakan di dalam Perjanjian Lama untuk mengambarkan hubungan antara Allah dan umat Israel. ${ }^{104}$ Ketika dipahami dengan tepat maka gagasan tentang kecemburuan Allah adalah inti bagi setiap konsep yang benar akan Allah, karena kecemburuan Allah beranalogi dengan kecemburuan yang semestinya dalam pernikahan. ${ }^{105}$ Dalam Perjanjian Lama Allah digambarkan sebagai suami dan umat Israel adalah istri (Yes. 54:5; 62:5 ; Hos. 2:19). Konsekuensinya Allah menuntut kasih dan kesetiaan umatNya secara total. Penyembahan berhala dan semua bentuk hubungan kompromi dengan para penyembah berhala dari bangsa lain menyebabkan ketidaktaatan dan ketidaksetiaan. Sama seperti seorang suami yang tidak bisa menerima atau toleran terhadap kekasih lain yang dimiliki oleh istrinya, demikian juga Allah tidak akan toleransi terhadap pihak lain yang ingin merampas hak-Nya atas Israel sebagai umat pilihan-Nya dan yang ingin merusak hubungan mereka.

John Calvin menjelaskan kebenaran ini:

Sebagaimana Allah yang telah mempertunangkan diri-Nya dengan kita dalam kebenaran akan menyatakan bahwa Ia akan terbakar dengan api cemburu jika kita mengabaikan kemurnian pernikahan dengan-Nya yang kudus serta menajiskan diri kita dengan hawa nafsu yang menjijikkan, dan terutama ketika penyembahan kepada-Nya yang harus dilakukan dengan

103 J. I. Packer, Knowing God, Tuntunan Praktis Untuk Mengenal Allah (Yogyakarta: Penerbit ANDI, 2008), 216.

104 James Hastings, Dictionary of the Bible, volume II (New York: Charles Scribner's Sons, 1901), 553.

105 James Montgomery Boice, Dasar-Dasar Iman Kristen. (Surabaya: Momentum, 2011), 134. 
teliti dan tanpa cela, dialihkan kepada orang lain, atau berzinah dengan beberapa takhyul. ${ }^{106}$

Allah memandang ketidaktaatan Israel dengan menyembah berhala sebagai perzinahan rohani dan membuat-Nya cemburu dan membalas dendam. Jadi kecemburuan Allah merupakan suatu perlindungan Allah terhadap bangsa Israel yang adalah milik-Nya.

\section{Kecemburuan Allah Atas Penyembahan Berhala Menyatakan Keadilan Allah}

Keadilan Allah merupakan salah satu unsur kekudusan Allah yang dapat terlihat dalam cara-Nya memperlakukan manusia sebagai ciptaanNya. Allah sendiri yang memperkenalkan diri-Nya sebagai Allah yang adil (Yes. 45:21). Sebagai Allah, Ia telah menetapkan hukum-hukum dan ketetapan-ketetapan yang harus ditaati oleh seluruh makhluk ciptaanNya dan sebagai Allah yang adil, ia juga telah menetapkan ganjaran atau sangsinya. Keadilan Allah ditunjukkan dengan cara memberikan hadiah atau pahala atau berkat bagi ketaatan dan pemberian hukuman bagi pelanggaran. ${ }^{107}$ Keadilan Allah menjadi nyata dalam kecemburuan-Nya. Kecemburuan Allah menuntun Dia untuk menghakimi dan menghancurkan orang yang tidak setia di antara umat-Nya, yang jatuh ke dalam dosa dan penyembahan berhala (Ul. 6:14; 32:16), dan menghakimi musuh kebenaran dan kemurahan di mana-mana (Nah. 1:2; Yeh. 36:5). Kecemburuan Allah juga menuntun Dia untuk memulihkan keadaan umat-Nya pada saat umat-Nya bertobat dan berbalik kepadaNya (Yeh. 39:25; Yes. 37:32).

Salah satu ekspresi dari kegairahan (kecemburuan) Allah adalah melalui murka-Nya terhadap segala pendurhakaan dan kenajisan dosa (Kel. $20: 5$; Ul. 5:9). ${ }^{108}$ Murka Allah tidak dapat dibandingkan dengan emosi apapun yang kita ketahui dalam pengalaman manusia. Murka Allah adalah sikap yang sepantasnya dan seharusnya dinyatakan oleh Allah yang kudus terhadap semua yang menentang Dia. ${ }^{109}$ Jadi murka Allah adalah ekspresi dari keadilan Allah yang menuntut penghukuman bagi orang berdosa. Dalam hal ini bagi orang yang menyembah berhala. Sedangkan kasih Allah adalah ekspresi keadilan Allah yang memberi berkat bagi orang-orang yang hidup di dalam ketaatan, menjaga dan

${ }^{106}$ Institues, II, viii, 18. Dikutip oleh J. I. Packer, Knowing God, Tuntunan Praktis Untuk Mengenal Allah (Yogyakarta: Penerbit ANDI, 2008), 217.

${ }^{107}$ Henry C. Thiessen, Teologi Sistematika (Malang: Gandum Mas, 2010), 129.

${ }^{108}$ S. H. Widyapranawa, Tafsiran Alkitab Yesaya 1-12 (Jakarta: BPK Gunung Mulia, 1974), 144.

109 James Montgomery Boice, Dasar-Dasar Iman Kristen (Surabaya: Momentum, 2011), 134 . 
memelihara perintah-perintah-Nya, dan bagi umat-Nya yang bertobat dan berbalik kepada-Nya. Dengan demikian, kecemburuan Allah menyatakan keadilan-Nya, baik dalam hal pemberian hukuman maupun dalam hal pemberian berkat.

\section{Implikasi Praktis Kecemburuan Allah Terhadap Penyembahan Berhala Berdasarkan Keluaran 20:4-6}

\section{Hanya Allah Satu-Satunya Yang Harus Disembah}

Allah saja yang harus disembah. Inilah yang tergambar melalui Hukum Kedua yang Allah berikan bagi bangsa Israel. Penyembahan kepada-Nya tidak dapat diberikan kepada yang lain karena tidak ada allah lain yang sama dengan Allah. Bukan hanya allah lain dalam bentuk patung atau gambar yang tidak boleh disembah, bahkan menyembah Allah dengan cara yang tidak benar yaitu melalui gambaran atau patung dilarang. Dalam pengertian ini, Allah cemburu sebab Ia mempertahankan hak-Nya sebagai satu-satu-Nya yang boleh disembah, dan Dia tidak akan memberikan kemuliaan-Nya kepada orang lain. ${ }^{110}$ Kecemburuan Allah menyatakan hanya Dialah yang harus disembah.

Dalam konteks masa kini, penyembahan kepada allah lain bukan lagi penyembahan kepada patung seperti pada zaman dulu lagi. Jerry Bridges menulis:

Kita bukan sedang menyembah berhala-berhala dari kayu, logam, dan batu pada masa kini. Masalah kita adalah apa yang oleh sebagian orang disebut "berhala-berhala hati". Dalam pengertian ini, sebuah berhala dapat berarti apa saja yang sangat kita junjung tinggi yang cenderung menyerap energi emosional dan mental kita, atau waktu sumber daya kita. Atau berhala dapat berupa apa saja yang kita dahulukan di atas relasi kita dengan Allah."11

Jadi penyembahan berhala adalah yang menghalangi relasi antara Allah dan manusia. Penyembahan kepada berhala kemudian bergeser menjadi sikap merendahkan nilai-nilai rohani, mengesampingkan kehidupan batin (kehidupan agama) dan lebih mementingkan kehidupan jasmani. Berhala bagi masing-masing orang berbeda: ada yang memuja harta kekayaan, ada yang memuja hobinya, kenikmatan seks,

${ }^{110}$ Ensiklopedi Alkitab Masa Kini Jilid l A-L, s.v. cemburu.

${ }^{111}$ Jerry Bridges, Respectable Sins Membereskan Dosa-dosa yang Kita Toleransi (Bandung: Pionir Jaya, 2008), 195-196. 
ada yang gila hormat dan ada pula yang mengagungkan kepandaian atau gagasannya. ${ }^{112}$ Berhala-berhala inilah yang disebut berhala modern.

Lebih jauh lagi James Montgomery menjelaskan bahwa:

Menyembah allah lain bukan saja dimaksudkan sebagai menyembah dewadewa atau berhala-berhala modern, melainkan termasuk juga di dalamnya setiap kali kita memberi orang tertentu atau hal tertentu tempat pertama dalam afeksi kita yang seharusnya menjadi milik Allah saja, contohnya diri kita sendiri, kesuksesan, harta, ketenaran, atau kuasa atas orang lain.113

Jadi hanya Allah satu-satunya yang harus disembah berarti bahwa orang percaya harus menyingkirkan hal-hal yang menghalangi mereka menyembah Allah yaitu berhala. Berhala termasuk segala sesuatu yang mengambil tempat pertama di dalam kehidupannya dan menempatkan Tuhan pada posisi itu. Orang percaya harus menyingkirkan segala sesuatu yang menjadi berhala dalam kehidupannya.

Hanya Allah satu-satunya yang harus disembah juga berarti orang percaya harus bersandar dan bergantung sepenuhnya kepada Allah yang layak dan pantas menjadi tempat bersandar dan bergantung. Konsekuensinya orang percaya harus hidup dan bertumbuh di dalam kesadaran penuh bahwa setiap hari dan setiap momen dijalani dalam hadirat Tuhan dan bahwa setiap orang bertanggung jawab kepada Dia. Tujuan dan sasaran hidupnya adalah untuk menyenangkan Tuhan dan memuliakan Dia dalam segala aktivitas baik dalam pekerjaan, usaha, maupun dalam kehidupan dalam keluarga dan jemaat.

\section{Orang Percaya Harus Menolak Penyembahan Berhala}

Sebagaimana seriusnya Allah menginginkan agar hanya Dialah satusatunya yang harus disembah, maka orang percaya dengan tegas harus menolak penyembahan berhala dalam bentuk apapun. Larangan akan berhala di Israel bukanlah karena berhala itu berwujud sedangkan Allah adalah Roh dan bukan pula karena berhala dapat dilihat sedangkan Allah tidak. Melainkan karena berhala itu tidak hidup, dan tak berdaya sedangkan Allah Israel hidup, berkarya dan berfirman. Itulah sebabnya satu-satunya gambaran Allah yang diperkenankan adalah gambaran yang Allah rancang dan ciptakan sendiri, yaitu manusia. Hanya manusia yang berakal budi, hidup, memilih, berbicara, bermoral, yang mencerminkan Allah yang hidup. Karena itu usaha apapun untuk menggambarkan Allah dalam objek-objek yang statis, atau tidak mempunyai kehidupan,

112 Al. Budyapranata pr, Etika Praktis Berdasarkan Sepuluh Perintah Allah (Yogyakarta: Yayasan ANDI, 1991), 7-8.

113 James Montgomery Boice, Dasar-Dasar Iman Kristen (Surabaya: Momentum, 2011), 253. 
bahkan dalam patung manusia, merendahkan Dia dan menolak unsur fundamental tentang Dia. Jadi, setiap orang percaya seharusnya menolak segala hal yang berusaha merendahkan diri Allah dalam bentuk apapun.

Dasar hukum ini sebenarnya terlihat melalui keberadaan Allah sendiri bahwa Allah adalah Roh. John F. Walvoord \& Roy B. Zuck menulis: "Penyembahan kepada Allah adalah bersifat roh dan bukan materi. Allah adalah Roh dan tidak ada materi representasi apapun yang mungkin bisa menyerupai Dia." 114 Itulah sebabnya Allah menghendaki agar Ia disembah dengan cara yang layak bagi-Nya dan tidak dengan cara menyembah patung. Mengapa penyembahan kepada patung dilarang karena usaha untuk menggambarkan Allah yang sejati adalah suatu hal yang mustahil. Penyembahan patung adalah suatu usaha untuk memutarbalikkan dengan radikal hubungan antara Pencipta dengan ciptaan. Allah menjadikan manusia menurut gambar-Nya. Maka orang yang membuat patung dan menyembah patung itu berusaha membuat Allah menurut gambar mahkluk. Penyembahan kepada patung itu tidak berpusat kepada Allah namun berpusatkan manusia. Dan siapa yang menyembah patung, ia menyembah dirinya sendiri, ia menyembah hasil karyanya sendiri.

Kebenaran yang luar biasa bagi orang percaya saat ini adalah sementara Allah yang melarang umat-Nya untuk membuat patung atau apapun yang menggambarkan Dia, telah memberi gambar-Nya sendiri yaitu Yesus Kristus yang mengambil wujud seorang manusia dan datang di antara kita, Dialah gambaran Allah (2 Kor. 4:4; Kol. 1:15). Allah menyatakan diri-Nya, oleh karena itu segala gambar, bayangan, pengertian, angan-angan, yang dipikirkan tentang Allah harus digantikan dengan gambar yang telah diberikan oleh Tuhan yaitu Yesus Kristus, satu-satu-nya gambar Allah. Dengan demikian Allah yang melarang penggambaran diri-Nya itu memanggil setiap umat-Nya untuk menolak penyembahan berhala dan hanya sujud menyembah kepada Yesus Kristus. Oleh karena itu, orang percaya harus menolak penyembahan berhala.

\section{Kecemburuan Allah Menjadi Dasar Penyembahan}

Hukum Kedua ini diberikan Allah dengan bernada negatif yaitu larangan untuk jangan membuat patung dan menyembah patung oleh karena Allah adalah Allah yang cemburu. Namun, lebih dalam lagi tersirat segi positif dari Hukum Kedua ini yaitu menyatakan bahwa Allah menghendaki agar Dia disembah dalam Roh dan Kebenaran. ${ }^{115}$ Allah adalah Roh, maka orang yang menyembah-Nya harus menyembah 
dalam roh dan kebenaran, bukan melalui patung. Jadi, Allah menghendaki agar Ia disembah dengan cara yang layak dan benar sesuai dengan keberadaan diri-Nya. Kecemburuan Allah bangkit karena Ia disembah dengan cara yang tidak layak. Oleh karena itulah kecemburuan Allah ini menjadi dasar penyembahan orang percaya.

Kecemburuan Allah harus diingat oleh setiap orang percaya setiap kali datang menyembah kepada Tuhan. Kecemburuan Allah pada intinya mengungkapkan kemurnian ibadah kepada Allah. Setiap orang percaya hendaknya menyembah Allah dengan cara yang mana Ia kehendaki. Oleh sebab itu, J Verkuyl kemudian bertanya: "Tuhan yang telah memberikan hati-Nya kepada kita, bertanya kepada kita dalam Perintah Kedua itu: Di manakah hatimu dalam kebaktian-kebaktianmu?"116 Pertanyaan ini tajam dan sangat dalam. Dalam kehidupan orang percaya masa kini, inilah yang harus di awasi jangan sampai dalam mengikuti ibadah dan persekutuan, hati dan fokusnya memikirkan hal yang lain. J. I. Packer menulis bahwa implikasi larangan penyembahan berhala oleh perintah kedua adalah umat Allah secara positif dan sepenuh hati harus mempersembahkan diri-Nya kepada pribadi Allah, rencana-Nya, dan kehormatan-Nya. Menarik kata Alkitab untuk penyerahan diri semacam ini adalah gairah, kadang-kadang disebut cemburu akan Allah. ${ }^{117}$ Dengan demikian kecemburuan Allah mendorong umat-Nya untuk semakin bergairah menyembah Allah.

Dalam pikiran modern di mana Allah telah menjadi hampir seperti manusia, begitu akrab sehingga kita tidak mengerti kemarahan-Nya yang kudus terhadap dosa setiap kali kita menyembah-Nya. Jika kita menyembah-Nya dengan kehidupan tanpa disertai pertobatan, pengakuan dosa, dan penyucian oleh Roh Kudus, kita akan terkena reaksi kudus-Nya. Kekudusan-Nya menandakan kecemburuan Allah. Jadi, kecemburuan Allah menantang orang percaya untuk bergairah dan bersungguh-sungguh dalam penyembahan kepada Allah.

\section{Penghukuman Sebagai Konsekuensi Bagi Penyembah Berhala}

Hukuman Allah telah tersedia sebagai ganjaran untuk setiap dosa dan pelanggaran terhadap ketetapan dan perintah Tuhan. Demikian pula para penyembah berhala pasti menerima konsekuensi atas perbuatannya. Penyembahan berhala selalu mendatangkan hukuman, karena Allah adalah cemburu. Dia Allah yang adil dan kudus. Allah yang kudus tidak mengabaikan dosa. Allah yang kudus membenci dosa sehingga orang percaya sebagai anak-anak Allah juga harus hidup dalam kebencian yang sama terhadap dosa dan menjauhi penyembahan berhala.

${ }^{116}$ J. Verkuyl, Etika Kristen Kapita Selekta (Jakarta: Badan Penerbit Kristen, 1961), 92.

117 J. I. Packer, Knowing God, Tuntunan Praktis Untuk Mengenal Allah (Yogyakarta: Penerbit ANDI, 2008), 219. 
Sekalipun sulit dilakukan pada zaman ini karena pengaruh dan godaan dunia begitu kuat. Apa yang dunia tawarkan selalu nampaknya menyenangkan. Penyembahan berhala juga terasa sangat menyenangkan sehingga orang percaya kadang tidak menyadari bahwa hal itu telah menjadi berhala dan mereka sementara menyembah berhala. Bahkan seringkali melihat kehidupan orang fasik jauh lebih baik dan menyenangkan dari pada kehidupan orang benar. Tetapi semua itu tidak boleh melemahkan iman dan menyurutkan semangat dan perjuangan orang percaya untuk terus bertahan hidup di dalam kekudusan. Sebab Allah yang adil pasti memberikan ganjaran berupa berkat atau pahala bagi ketaatan. Allah tidak pernah menutup mata untuk setiap perjuangan melawan penyembahan berhala dan hidup di dalam kekudusan. "Sebab itu haruslah kau ketahui, bahwa Tuhan, Allahmu, Dialah Allah, Allah yang setia, yang memegang perjanjian dan kasih setia-Nya terhadap orang yang kasih kepada-Nya dan berpegang pada perintah-Nya, sampai kepada beribu-ribu keturunan" (Ul. 7:9). Keadilan Allah tidak bisa dinilai berdasarkan jangka pendek sebab keadilan Allah akan sempurna di dalam kekekalan. ${ }^{118}$ Oleh karena itu orang percaya masa kini perlu berhati-hati karena penyembahan berhala selalu mendatangkan hukuman oleh sebab keadilan Allah bekerja dalam kehidupan manusia.

\section{Kasih Menjadi Dasar Relasi Dengan Allah}

Kasih Allah yang begitu besar digambarkan sebagai kecemburuan, yaitu suatu gairah yang sangat kuat dan semangat yang bernyala-nyala harus menjadi dasar relasi dengan Allah. Sepatutnyalah orang percaya untuk mengasihi Allah dengan kasih yang sama besarnya sesuai dengan ukuran kodratnya sebagai manusia, karena orang percaya sebagai manusia tidak akan mungkin menyamai kasih Allah. Inilah yang dikehendaki Tuhan ketika berkata: "Kasihilah Tuhan, Allahmu, dengan segenap hatimu dan dengan segenap jiwamu dan dengan segenap akal budimu" (Mat. 22:37). Kata "segenap" berarti penuh, utuh (tidak kurang), lengkap. ${ }^{119}$ Kehendak Tuhan agar setiap orang percaya mengasihi-Nya dengan segala kepenuhan yang dimiliki. Kasih yang seperti inilah yang seharusnya menjadi motivasi dan dasar dari ketaatan kepada Tuhan, sekaligus menjadi motivasi dan dasar bagi penyembahan dan ibadah kepada Tuhan. Karena bagi Tuhan, ketaatan kepada-Nya adalah bukti mengasihi-Nya (Yoh. 14:15).

Dengan demikian kasih Allah yang dinyatakan melalui kecemburuan-Nya seharusnya mendorong orang tetap setia mengasihi

${ }^{118}$ Millard J. Erickson, Teologi Kristen Vol. 1 (Malang: Gandum Mas, 2004), 463.

${ }^{119}$ Kamus Umum Bahasa Indonesia, s.v. "genap" 
Allah dan itu juga terwujud dalam kasih terhadap sesama yang juga adalah milik Allah, sebagaimana dasar kecemburuan Allah sendiri adalah kasih bagi umat-Nya yang adalah milik-Nya.

\section{Kesimpulan}

Berdasarkan seluruh uraian artikel ini, maka dapat ditarik kesimpulan mengenai kecemburuan Allah terhadap penyembahan berhala dalam Keluaran 20:4-6 yaitu sebagai berikut.

Pertama, kecemburuan Allah terhadap penyembahan berhala menyatakan bahwa Allah tidak dapat direpresentasikan dalam bentuk apapun karena kecemburuan Allah ini menyatakan bahwa Ia adalah Allah yang kudus. Dengan demikian, hanya Allah satu-satunya yang harus disembah oleh orang percaya.

Kedua, kecemburuan Allah terhadap penyembahan berhala menyatakan bahwa tidak boleh ada objek penyembahan yang lain selain kepada Allah karena penyembahan kepada berhala menandakan perzinaan rohani yang mengakibatkan kecemburuan Allah. Oleh karena itu, orang percaya harus menolak segala bentuk penyembahan berhala.

Ketiga, penyembahan kepada berhala mendatangkan kecemburuan Allah karena kecemburuan Allah ini menyatakan kesetiaan-Nya atas perjanjian dengan umat-Nya. Dengan demikian, kecemburuan Allah seharusnya menjadi dasar dari penyembahan kepada Allah.

Keempat, kecemburuan Allah atas penyembahan berhala mendatangkan hukuman karena kecemburuan Allah menyatakan keadilan-Nya dalam hal pemberian hukuman sebagai konsekuensi bagi penyembah berhala.

Kelima, kecemburuan Allah atas penyembahan berhala menyatakan bahwa Allah mengasihi umat-Nya dan sekaligus menyatakan keadilan Allah dalam hal pemberian berkat bagi yang mengasihi-Nya. Kasih Allah mendasari hubungan-Nya dengan umat-Nya, dengan demikian kasih juga menjadi dasar hubungan orang percaya dengan Tuhan.

\section{Kepustakaan}

Alkitab Edisi Studi. Jakarta: Lembaga Alkitab Indonesia, 2010.

Amzallag, Nizzim. "Furnace Remelting as the Expression of YHWH's

Holiness: Evidence from the Meaning of $q a n n \vec{a}(ק נ א)$ in the Divine

Context" Journal of Biblical Literature. Vol. 134 No. 2 (2015): 233-252.

Baker, D. L, S. M. Siahaan, A. A. Sitompul. Pengantar Bahasa Ibrani. Jakarta:

BPK Gunung Mulia, 2010. 
Barth, C. Teologia Perjanjian Lama Jilid Pertama. Jakarta: BPK Gunung Mulia, 1991.

Benner, Jeff A. "Ancient Hebrew Research Center", Diakses 4 Desember 2012, http://www.ancient-hebrew.org/5_creator.html

Boice, James Montgomery. Dasar-Dasar Iman Kristen. Surabaya: Momentum, 2011.

Bridges, Jerry. Respectable Sins Membereskan Dosa-dosa yang Kita Toleransi. Bandung: Pionir Jaya, 2008.

Budyapranata pr, Al. Etika Praktis Berdasarkan Sepuluh Perintah Allah. Yogyakarta: Yayasan ANDI, 1991.

Buttrick, George Arthur. The Interpreter's Bible The Holy Scriptures Volume I General And Old Testament Articles Genesis-Exodus. Nashville: New York Abingdon Press, 1952.

Craigie, P. C. The New International Commentary on the Old testament, The Book of Deuteronomy. Grand Rapids Michigan: William B. Eerdmans Publishing Company, 1979.

Davidson, F. A. M. Stibbs, E. F. Kevan. The New Bible Commentary. Grand Rapids, Michigan: WM. B. Eerdmans Publishing Company, 1965.

Douglas, J. D. Ensiklopedi Alkitab Masa Kini Jilid 1. Jakarta: Yayasan komunikasi bina kasih, 1992.

Dummelow, J. R. A Commentary On The Whole Bible by Various Writers Complete In One Volume. New York: The Macmillan Company, 1923.

Ellicott, Charles John. Ellicott's Commentary On The Whole Bible A Verse By Verse Explanation. Grand Rapids, Michigan: Zondervan Publishing House, 1959.

Ensiklopedi Alkitab Masa Kini Jilid l (A-L), Jakarta: OMF. 1995.

Erickson, Millard J. Teologi Kristen Vol. 1. Malang: Gandum Mas, 2004.

Gaebelein, Frank E. The Expositor's Bible Commentary with The New International Version Volume 2. Grand Rapids, Michigan: Zondervan Publishing House, 1990.

Harris, W. T. \& F. Sturges Allen. Webster's New Internasional Dictionary of the English Languange. Springfield, Mass., USA: G \& C Merriam Company, 1915.

Hastings, James. Dictionary of the Bible, volume II. New York: Charles Scribner's Sons, 1901.

Henry, Matthew \& Thomas Scott. Commentary On The Holy Bible With Explanatory Notes From Other Writers Genesis - Esther. Nashville, New York: Thomas Nelson Publishers, 1798.

Keil, C. F. and F. Delitzsch. Commentary On The Old Testament In Ten Volumes Volume I The Pentateukh. Grand Rapids, Michigan: William B. Eerdmans Publishing Company, 1975. 
Labberton, Mark. Bahaya Ibadah Sejati Sebuah Panggilan Memerangi Ketidakadilan. Surabaya: Literatur Perkantas Jawa Timur, 2011.

Orton, David. Ular-ular Dalam Gereja. Yogyakarta: Penerbit ANDI, 2005.

Packer, J. I. Knowing God, Tuntunan Praktis Untuk Mengenal Allah. Yogyakarta: Penerbit ANDI, 2008.

Patterson, Robert M. Tafsiran Alkitab Kitab Keluaran. Jakarta: BPK Gunung Mulia, 2006.

Pfeiffer, Charles F. \& Everett F. Harrison. Tafsiran Alkitab Wycliffe, Vol.1 Perjanjian Lama: Kejadian-Ester. Malang: Gandum Mas, 2004.

Pink, Arthur W. Gleanings In Exodus. Chicago: Moody Press, 1978.

Spence, H. D. M. and Joseph S. Exell. The Pulpit Commentary Exodus Volume 1. Chicago: Wilcox \& Follett Co., n.d.

Strong, James. Strong Exhaustive Concordance of the Bible, Reference Library Edition. Iowa Falls, Iowa: World Bible Publishers, n.d.

Studi Alkitab. Hukum Taurat: Hukum Kedua, Diakses 8 Mei 2014, http://www.studialkitab.com/2010/04/hukum-taurat-hukum-ke-2.html

Tafsiran Alkitab Masa Kini 1 Kejadian-Ester. Jakarta: BPK Gunung Mulia untuk Yayasan Komunikasi Bina Kasih/OMF, 1982.

Thiessen, Henry C. Teologi Sistematika. Malang: Gandum Mas, 2010.

Unger, Merrill F, William White, Jr., Nelson's Expository Dictionary of the Old Testament. Nashville: Thomas Nelson Publishers, 1980.

Verkuyl, J. Etika Kristen Kapita Selekta. Jakarta: Badan Penerbit Kristen, 1961.

Walvoord, John F.\& Roy B. Zuck, The Bible Knowledge Commentary an Expositon of the Scriptures by Dallas Seminary Faculty Old Testament. Wheaton, Illinois: Victor Books a division of SP Publication, Inc, 1986.

Widyapranawa, S.H. Tafsiran Alkitab Yesaya 1-12. Jakarta: BPK Gunung Mulia, 1974.

Wilson, William. Wilson's Old Testament Word Studies. Mclean: Mac Donald Publishing Company, n.d. 